NBER WORKING PAPER SERIES

\title{
THE "VIRTUES" OF THE PAST: EDUCATION IN THE FIRST HUNDRED \\ YEARS OF THE NEW REPUBLIC
}

\author{
Claudia Goldin \\ Lawrence F. Katz \\ Working Paper 9958 \\ http://www.nber.org/papers/w9958
NATIONAL BUREAU OF ECONOMIC RESEARCH 1050 Massachusetts Avenue
Cambridge, MA 02138
September 2003

The authors gratefully acknowledge support from the Spencer Foundation (Major Grant no. 200200007) and the research assistance of Leah Platt. Authors' Note: This essay is Chapter 4 of Claudia Goldin and Lawrence F. Katz, The Race between Education and Technology: Interrelationships between the Economy and Human Capital in U.S. History (in progress). The several chapters that follow largely concern the consequences of educational systems in the United States during the twentieth century. In this chapter we explore the origins of the fundamental features of those institutions. The views expressed herein are those of the authors and not necessarily those of the National Bureau of Economic Research.

(C)2003 by Claudia Goldin and Lawrence F. Katz. All rights reserved. Short sections of text, not to exceed two paragraphs, may be quoted without explicit permission provided that full credit, including $\odot$ notice, is given to the source. 
The "Virtues" of the Past: Education in the First Hundred Years of the New Republic Claudia Goldin and Lawrence F. Katz

NBER Working Paper No. 9958

September 2003

JEL No. N3, I2

\section{$\underline{\text { ABSTRACT }}$}

By the mid-nineteenth century school enrollment rates in the United States exceeded those of any other nation in the world and by the early twentieth century the United States had accomplished mass education at all levels. No country was able to close the gap until the last quarter of the twentieth century. For much of its history U.S. education was spurred by a set of "virtues," the most important of which were public provision by small fiscally independent districts, public funding, secular control, gender neutrality, open access, a forgiving system, and an academic curriculum. The outcomes of the virtues were an enormous diffusion of educational institutions and the early spread of mass education. America borrowed its educational institutions from Europe but added to them in ways that served to enhance competition and openness. The virtues of long ago need not be the virtues of today, and they also need not have been virtuous in all places and at all times in the past. In this essay we explore the historical origins of these virtues and find that almost all were in place in the period before the American Civil War

Claudia Goldin

217 Littauer Building

Department of Economics

Harvard University

Cambridge, MA 02138

and NBER

cgoldin@harvard.edu
Lawrence F. Katz

215 Littauer Building

Department of Economics

Harvard University

Cambridge, MA 02138

and NBER

lkatz@harvard.edu 
Table of Contents

Section $\quad$ pages

I. The virtues of American education .................................................................................... 1

II. The origins of the virtues: the first hundred years of the republic ................................... 8

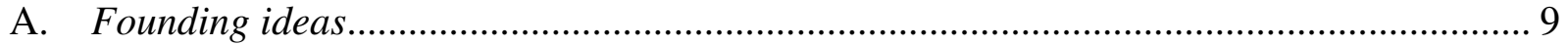

B. Public provision of schooling by small, independent localities (Virtues 1 and 2) ........... 10

1. Common schools in the early republic.................................................................. 10

2. Decentralization of control .............................................................................. 11

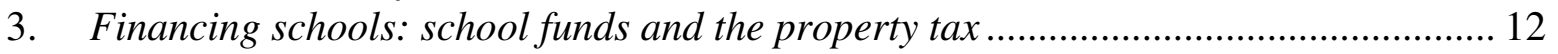

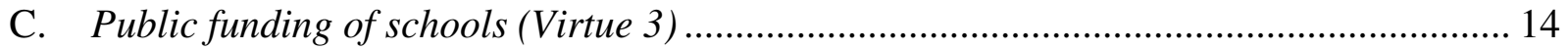

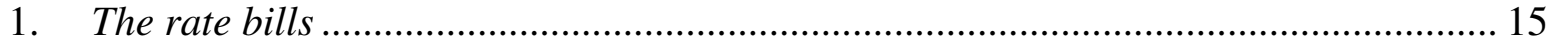

2. Free schooling for all: the common school crusade .................................................. 18

3. How important was the common school movement? ................................................ 19

4. Horace Mann and the "school men" ....................................................................... 24

5. Was "free schooling for all" a grass roots movement or was it imposed? ................. 26

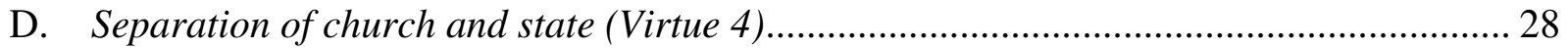

1. Nonsectarianism ......................................................................................... 28

2. The origins of free and nonsectarian urban schools: New York City as a case study.. 29

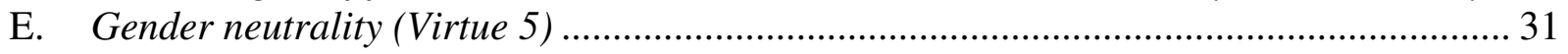

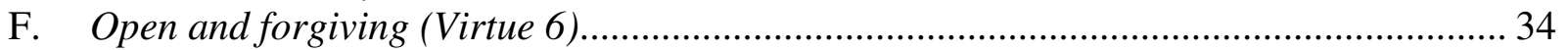

III. A note on nineteenth century education statistics ................................................... 35

IV. The origins of public high schools: from common schools, grammar schools, and

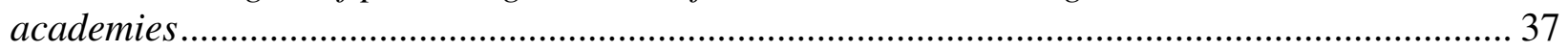

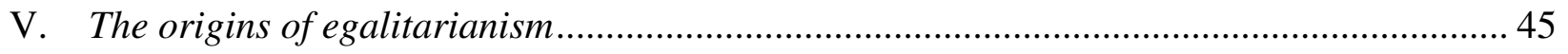

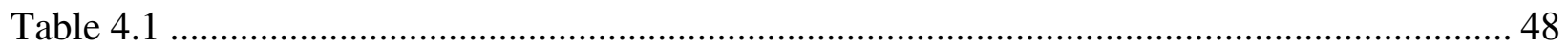

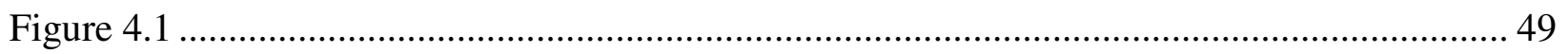

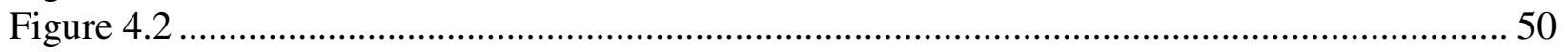

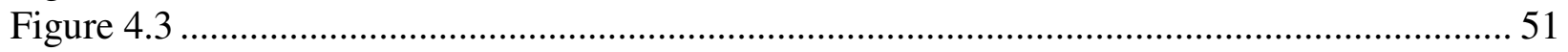

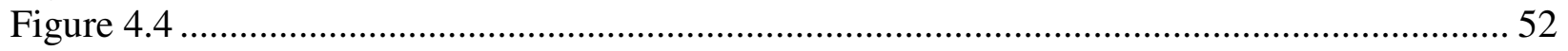

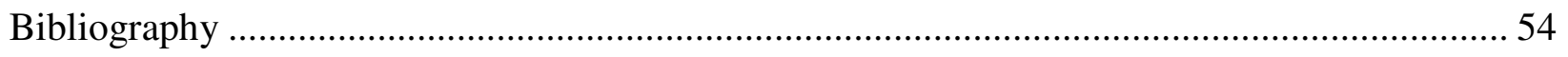


The key features of U.S. educational institutions in 1900—which we will term the "virtues"- had largely taken shape in the preceding century and most had emerged in the period before the American Civil War. These virtues would determine U.S. educational development in the twentieth century and would enable the United States to lead the world in schooling for the masses. The subject of this chapter is the origin of these defining features during the republic's first hundred years.

These features include the three most basic: public funding, public provision, and the separation of church and state. Three others were fundamental: a decentralized system containing thousands of fiscally-independent districts, an open structure in which youthful transgressions were often forgiven, and the ability of girls to receive instruction in coeducational public schools, which we term gender neutrality. These characteristics are so often taken for granted that it would seem inconceivable that there was ever a time in the history of the United States when they did not exist. But, indeed, there was.

\section{The virtues of American education}

Many of the features that were in place around 1900 are ones we will deem the "virtues" of the U.S. elementary and secondary educational system. By virtues we mean a set of characteristics that originated in basic democratic and egalitarian principles and that influenced the educational system.

The virtues include public provision by small fiscally independent districts, public funding, secular control, gender neutrality, open access and a forgiving system, and an academic curriculum. These virtuous features have been summarized by the word "egalitarianism." They have held the promise of equality of opportunity and a common education for all U.S. children. 
The outcome of the virtues was the enormous diffusion of schooling and educational institutions throughout much of the young nation. By the mid-nineteenth century, enrollment rates among children and youth in the United States exceeded those of any other nation in the world. ${ }^{1}$ One of the reasons that we deem these features "virtues" is that they produced a relatively high level of schooling and educational attainment. ${ }^{2}$ They did so from the midnineteenth century and continued to do so to the latter part of the twentieth century.

The U.S. lead in primary schooling would narrow toward the end of the nineteenth century as parts of Europe began to educate their masses. But its lead would be greatly expanded in the early part of the twentieth century as America was swept up in the high school movement and in subsequent decades as mass higher education took hold. The preeminence of the United States in mass education continued up to the last 30 years. But this is getting somewhat ahead of our story.

The virtues of long ago need not be the virtues of today. They also need not have been virtuous in all places and at all times in the past. We will make a case, for example, that the existence of numerous and small fiscally independent school districts was an important virtue of the past and that it enabled educational progress. But small fiscally independent districts with their widely divergent levels of taxable land and real estate are often seen today as a serious drawback to educational advances and a source of inequitable education.

The openness and forgiveness of the U.S. educational system is another example. These features enabled youths to make up for deficits in their backgrounds and to evade severe

\footnotetext{
${ }^{1}$ See Easterlin (1981) and Lindert (2000), for example. We will, however, raise questions later in this chapter about the levels of enrollment in the early U.S. census data and the attendance data for selected states.

${ }^{2}$ We distinguish between "schooling," for which we mean the contemporaneous level of enrollment, attendance, or graduation, and "education," for which we mean the average years (and quality) of schooling attained by a population.
} 
penalties for the misdeeds of their past. But these features are often viewed today as an excuse for schools to lower academic standards and for teachers to avoid having to deal with problem students. Yet another example is local control in educational funding and decision-making. Decentralization may have facilitated rapid educational progress across many communities. But local control also meant that de jure racial segregation persisted in many southern cities even after Brown v. Board of Education (1954) and that de facto segregation existed in countless cities outside the South.

The features we will deem as virtues were often accompanied by corollary or accessory characteristics. For example, the existence of large numbers of fiscally independent districts meant that small localities were required to raise funds for schools. Real estate taxation was the most effective means of funding education, in part because land cannot migrate whereas most other forms of capital can and do so in response to taxation. The existence of small, local school districts meant that minor governmental units, such as townships, could compete for residents along many dimensions.

The virtuous aspects of these features were not always intentional, as in the case of the small fiscally independent school districts. There were practical reasons to have large numbers of small independent school districts in rural America and they derived as well from the American desire for community control and local taxation. Similarly, the more vicious aspects of these same features may also have been unintentional and their unintended consequences may have worsened over time. With rising inequality over the past several decades, geographic sorting on the basis of income has become more extreme. ${ }^{3}$ Some districts became considerably richer than others and had better schools. Many have deemed this outcome a non-virtuous aspect of having small fiscally independent districts. 
But, for some time and in many places in America, the features we just described gave rise to extraordinarily beneficial outcomes. These outcomes were far better than were those of other countries, which often had educational systems with diametrically opposing characteristics. If the decentralization of America led to the growth of mass secondary schooling, then the centralization of control that characterized most European school systems stifled it. If an open and forgiving system gave disadvantaged and errant youths a second chance, then the insistence on standards and accountability of many European systems reinforced a caste system. It is, in part, for these reasons that we deem the features of the U.S. educational system as virtues, at least for much of the period we will later discuss.

The most important of the features of U.S. education around 1900 were the public funding and the public provision of elementary and secondary schools. These twin characteristics formed the essence of public education. Schooling was not only publicly funded, but it was also provided by tens of thousands of fiscally independent school districts. Some of these districts, mainly those of the nation's large cities, served enormous numbers of children and were geographically large as well. But the vast majority of districts in 1900 were small in terms of their geographic dimensions and the number of children they served. The majority of children, moreover, resided in relatively small districts. The nation's school system, therefore, was a highly decentralized one at the start of the twentieth century and it has remained decentralized to the present day, although not nearly to the same degree that it once was. ${ }^{4}$

\footnotetext{
${ }^{3}$ Watson (2002) documents the rise in U.S. residential segregation by economic status since 1970.

${ }^{4}$ The U.S. Office of Education did not collect information on the number of school districts until 1932 when there were 127,531 (U.S. Bureau of the Census 1975, series H 412). It is likely that there were more in 1900. Even though some school districts were extremely large, for example the New York City school district enrolled almost 560,000 school children in 1900, most youth lived in small towns and rural areas in 1900. Only 22 percent of 5 to 14 year olds lived in cities with more than 25,000 people and 27 percent resided in cities with more than 10,000. Fully 60 percent lived in rural areas or towns with fewer
} 
Education in terms of its funding, staffing, and curriculum, therefore, was largely a local affair at the turn of the twentieth century. In 1900 the U.S. federal government had virtually no involvement in primary and secondary education, although it had once served an important role in the granting of federal lands for educational funding. Far later in the twentieth century, the federal government would take on an increasingly important, yet still relatively modest, role. Most states around 1900 also played a relatively small fiscal role in education. In its decentralization, the U.S. system was, and continues to be, the polar opposite of many of its European counterparts. ${ }^{5}$

Decentralization is not the only contrast that existed between the American and European elementary and secondary school systems. Perhaps the most important difference around 1900 was that U.S. schooling was not an elite system in which only a small number of bright young men could attain an upper secondary school education and thus continue their studies in a college or university. Schools were, by and large, open to all and were highly forgiving to those who did poorly in the lower grades.

There was also extensive gender equality in U.S. education and this is another of the virtues of the American system. High school entering classes in 1900, for example, contained an

than 1,000 persons. Sources: U.S. Office of Education, Annual Report (1900-01), p. 1547; U.S. Bureau of the Census (1975), series A 57-72; IPUMS for the 1900 U.S. census of population.

${ }^{5}$ Lindert (2000) emphasizes the role of decentralization in spurring educational advances in the nineteenth century. According to Lindert, the United States, Canada, and Prussia had decentralized systems, while Great Britain and Scandinavian countries were highly centralized allowing national elites to gain control of educational decisions. Even though Prussia is deemed "decentralized" by Lindert, Ringer (1979, p. 32) notes that "a fairly homogeneous national system of education emerged even before 1870, especially at the secondary and university levels." The imposition in 1812 of state "leaving exams" in Prussia underscores the centralization of educational control. See also Fishlow (1966b, p. 435) on the growth of centralization in Europe relative to the United States in the late nineteenth century. According to Fishlow local sources in England provided 75 percent of primary school income in 1876 with half coming from private sources, but by 1900 Parliamentary grants exceeded 50 percent of income and private fees had been eliminated. France, which had been highly centralized for both fiscal and curriculum matters further centralized in the late nineteenth century. In 1877, according to Fishlow, the 
almost equal number of boys and girls. But considerably more girls than boys were in attendance in the upper secondary school grades and a larger proportion eventually graduated. Although gender neutrality existed in the ability of girls to obtain more years of schooling at least through secondary school, gender neutrality in the quality of schooling may be another matter although we believe it was not.

Equality in education was not ubiquitous across all groups, of course. In 1900, AfricanAmerican youth were educated in segregated schools throughout the South and they were once educated in de jure segregated schools in parts of the North as well. The South's segregated schools were not "equal" in any manner, despite the 1896 Plessy v. Ferguson decision of the U.S. Supreme Court, which was interpreted to mean that schools could be separate only if they were equal. In the North, furthermore, many poor children, often of immigrant parents, were educated in inadequately funded schools even when other schools in the same district were better funded. Yet educational advances touched more children in the United States than they did in Europe and enabled considerably more youth to advance to secondary schools and even to higher education until well into the twentieth century.

In opposition to some European educational systems in the early twentieth century and later, U.S. secondary schools offered academic programs that were rarely connected to industry or with labor unions. Their programs trained students to enter college or to begin various jobs. Around 1910, particularly for those living in cities and towns, the jobs that most high school graduates entered were mainly in the white-collar sectors. ${ }^{6}$ Secondary schools, in the years to

French central government provided 25 percent of public primary school revenue but by 1900 it accounted for 80 percent. Fishlow notes a similar trend in Prussia with respect to its school-tax law. ${ }^{6}$ Burdge (1921) reports the findings of a 1918 New York State survey of all 16 to 18 year old males in the state. Among employed boys who graduated high school and were from cities with more than 25,000 residents, 92 percent indicated they wanted to work in white-collar occupations and 82 percent were currently employed in such jobs. In contrast, among those who completed no years of high school 57 
come, would place increasing emphasis on vocational and life-style courses and the change in curriculum would lead many to take a less academic "track."

Finally, public education in the United States was secular by 1900 in the sense that organized religious groups generally did not receive local and state funds to run schools. Nonsectarian education did not mean that bibles and prayer were absent from the public school classroom, for they remained part of it for a long time. The separation of church and state in the provision of public education that existed in 1900 was largely the doing of the states, not the federal government. In contrast, the interpretation of the "Establishment Clause" of the U.S. Constitution is an important feature of more recent school debates and it may one day shape the future of vouchers and even that of the common school system of education. ${ }^{7}$

All the virtues mentioned that existed in 1900— public provision and funding, secular control, gender neutrality, an open and forgiving system, and an academic curriculum-were distinguishing features of U.S. elementary and secondary education long before the start of the twentieth century. Similarly, the U.S. higher education system contained distinctively American features that had been formed prior to 1900.

Higher education in the early twentieth century United States was open, flexible, geographically close to its primarily rural constituency, connected to state and local concerns,

percent desired white-collar jobs and 46 percent were currently employed in them. White-collar jobs include beginning employments in the office sector, such as "mail boy" and "office clerk." The 1915 Iowa state census gives similar results. Among male 18 to 24 year olds living in Iowa's larger cities, 82 percent of high school graduates were white collar workers whereas just 21 percent of those without any high school were. For women in the same age group the fractions are 95 percent for high school graduates and 41 percent for those with no high school (see Goldin and Katz 2000, on the Iowa 1915 state census sample).

${ }^{7}$ The first amendment (the "Establishment Clause") says: "Congress shall make no law respecting an establishment of religion, or prohibiting the free exercise thereof." The Supreme Court decision, Zelman v. Simmons-Harris (no. 00-1751, June 27, 2002), which upheld the use of public vouchers by parents to send their children to religious schools in Cleveland, may have important consequences in general for the use of vouchers by denominational institutions and, more important, for the nation's public school systems. 
practical in its curriculum, and diverse in many dimensions. It contained a wide-ranging, viable private sector and a growing multi-layered public sector. Competition existed both between and within the public and private sectors. In these many ways the institutions of American higher education differed greatly from those in most European nations. But, as in the case of secondary education and probably to a far greater extent, further distinctive characteristics would take shape in the decades after 1900. Changes in the scale and scope of higher education institutions over the ensuing decades were to fundamentally alter the roles of American higher education. ${ }^{8}$

\section{The origins of the virtues: the first hundred years of the republic}

We begin our brief history of U.S. education at the dawn of the new republic. Our concern is with the origins of (1) the public provision of education, thus the establishment of "common" schools; (2) small fiscally-independent districts, thus decentralization; (3) public funding of schools, thus a free education for all; (4) non-sectarian public schools, thus the separation between church and state in educational finance and control; (5) gender neutrality in access to public education, thus a public education regardless of sex; and (6) an open and forgiving system, thus mass education. Taken together these virtues produced egalitarianism. These characteristics are not necessarily independent in their origins and in their existence. Virtues (1) and (2), for example, are intricately connected and our discussion aggregates them.

We will focus here on common or elementary education because they diffused largely in the nineteenth century whereas secondary and higher education diffused in the twentieth century. Mass secondary schooling in the early twentieth century was made possible because universal

\footnotetext{
${ }^{8}$ Goldin and Katz (1999a) analyze the factors that drove these changes and their impacts on U.S. higher education.
} 
elementary school education had already spread throughout most sections of the nation. ${ }^{9}$ Mass elementary school education, in turn, had been made possible because public education was by the 1870 s, at the latest, free throughout the nation.

\section{A. Founding ideas}

Many patriots of the new nation and signers of the Declaration of Independence such as John Adams, Benjamin Franklin, Thomas Jefferson, and Benjamin Rush wrote extensively about educational institutions. In some instances, for example the Massachusetts Constitution of 1780 drafted by John Adams, their ideas were widely shared and quickly adopted. ${ }^{10}$ But that was not often the case and most of their plans never bore fruit. Although many of their statements about education were deeply held by themselves and most other Americans, some of their writings were propaganda tracts to help speed the development and integration of the new republic. But, whatever their intent or immediate success, these treatises and other writings helped coalesce a growing sentiment in the new nation for a strong educational foundation. Perhaps most important is that their ideas speak to the concerns of those who formed the union, who viewed it both from on high and from the ground up. ${ }^{11}$

Almost all of these authors wrote compellingly of the critical importance of education in a democracy so that Americans could perform their civic functions as citizens, such as voting, and so that they could run for office and lead the nation. Some revolutionary thinkers had more

\footnotetext{
${ }^{9}$ See Goldin and Katz (1999b, 2003a,b) on the high school movement and spread of mass secondary schooling in the United States during the first-half of the $20^{\text {th }}$ century.

10 "Wisdom, and knowledge ... depend on spreading the opportunities and advantages of education in the various parts of the country ... it shall be the duty of legislatures and magistrates, in all future periods of this commonwealth, to cherish the interests of literature and the sciences, and all seminaries of them; especially the university at Cambridge, public schools and grammar schools in the towns" (Constitution of the Commonwealth of Massachusetts, chapter V, section II). For state constitutions (and their changes over time) see John Wallis's, University of Maryland and NBER State Constitutions Project, which at the time of this writing was located at http://129.2.168.174/constitution/.
} 
visionary ideas concerning the role of education and how the nation's educational system should be organized. Jefferson and Rush, for example, elaborated schemes for entire educational systems ranging from elementary schools to colleges and universities. Jefferson's plan for Virginia contained three levels of schooling. At the bottom level, elementary schools would be open to all and publicly funded. Academies, at the middle level, were to be publicly funded and available to able boys. William and Mary College was the highest level and would award scholarships to needy, bright boys. Ironically, given his political views on the relative role of the federal and state governments, Jefferson's plan may have failed because it was insufficiently local in its funding.

To Benjamin Rush, the most prominent physician of his age and a renowned public figure, education mattered not only for the infant democracy, but also for its economy. Expenditures on education, according to Rush, would lessen taxes because they would increase "the profits of agriculture and [promote] manufacturing." He called for the study of practical subjects, a curriculum that would soon become part of the quintessentially American form of education. "Agriculture," he aptly noted, "is as much a science as hydraulics or optics." 12 "The study of Commerce and the principles of Money," he more idealistically suggested, would have an "effect as next to those of religion in humanizing mankind." 13

\section{B. Public provision of schooling by small, independent localities (Virtues 1 and 2)}

\section{Common schools in the early republic}

Schools existed everywhere in the early republic for free youths of all ages, in communities of every size, much as they had done prior to the revolution. The schools were

\footnotetext{
${ }^{11}$ See Kaestle (1983) for a fine introduction to this literature and Rudolph (1965) for some of the primary sources.

${ }^{12}$ Benjamin Rush, "Plan for the Establishment of Public Schools," (1786) in Rudolph (1965), p. 4, 6.
} 
often termed "common schools," a name that persisted into the twentieth century in rural areas. In most towns these schools were eventually called elementary schools and in some cities grammar schools existed for the older students. For simplicity of usage, we will call all schools in the pre-1870 era that educated young children "common schools," even though many of them included older children as well and even though some were graded by age and would have been termed elementary or grammar schools.

The phrase "common school education" has meant many things and the term continued in use for nearly a century and a half. In the early nineteenth century, a common school meant one that was publicly maintained and belonged to the community. The term was used in opposition to a private school, either secular or denominational. On a practical level it connoted an inclusive school, one of all the people and "common" to them. A common school bound the community together and taught commonly held principles and elementary subjects. As the graded elementary schools of the towns and cities increased in number and size by the early twentieth century, the common school came to mean the one-room schoolhouse of the "open country" of rural America.

\section{Decentralization of control}

The common schools of the early republic were organized at the local level and were funded in a variety of ways. "Local" did not always mean exactly the same type of governmental unit in all parts of the nation and its meaning has changed over time within regions. The New England township was for most of its history the smallest unit that governed its school finance and curricula decisions. The New England township joined the residents of a town with those of the various rural and village communities that surrounded it. A smaller

\footnotetext{
${ }^{13}$ Benjamin Rush, "Thoughts Upon the Mode of Education Proper in a Republic," (1786) in Rudolph (1965), p. 19.
} 
unit—the school district—had once been the locus of school governance in Massachusetts and existed until the 1840 s. ${ }^{14}$

The New England township model was replicated in much of the nascent Midwest. But school districts, of varying sizes, were the smallest levels of educational governance in other parts of the young nation including certain parts of the Midwest. Thus the jurisdictional unit for educational decision-making ranged in size and in organizing principle. There were township communities in New England, groups of farm families in the newer states, and religious parishes in Connecticut, to list just a few.

\section{Financing schools: school funds and the property tax}

Even though schooling was, by and large, a local concern in the nineteenth century, both state and federal governments played important enabling roles. That the states played a role in the nineteenth century should not be surprising since education is one of the powers reserved to the states by the $10^{\text {th }}$ Amendment of the U.S. Constitution.

Most Americans in the period of the early republic, if we infer from their behavior, preferred that their local communities provide for their children's education and that these localities levy the taxes to pay for some or all of the expenses. But localities did not initially have taxing authority and states had to pass enabling legislation to allow localities to impose taxes. Most of the states of the Northeast passed legislation by the 1820 s allowing towns to impose taxes. Connecticut did so in 1794, Rhode Island in 1828, and New Jersey in 1829.

States later passed legislation that forced localities to provide schooling free of charge for the full length of the school year. Massachusetts, in 1827, required that towns exceeding 50 families support their schools through taxation since it had foreclosed the possibility raising funds for teachers through a "user tax" with its abolition of the rate bill, which we discuss later,

\footnotetext{
${ }^{14}$ Kaestle and Vinovskis (1980), chapter 5.
} 
in 1826. Some states, such as New York, provided matching funds to localities for various school expenses, including teacher salaries and school buildings. ${ }^{15}$

The benefits of decentralized financial control concern the efficiency gains that result through greater competition in the provision of education. Equity effects, however, can go in the opposite direction since the expected dispersion of per student expenditures decreases as the centralization of finances increases. ${ }^{16}$ But within this important trade-off of equity and efficiency in the provision of local public goods, the property tax looms large. ${ }^{17}$ The use of a particular type of taxation as opposed to an income tax, for example, has played an important role in the local finance of education.

Under local control with a property tax, the benefits of a better school system get capitalized into the price of housing. With a constant tax rate the increased value of housing gets translated into greater revenue for the district. ${ }^{18}$ Thus the decentralization of fiscal control, the large number of fiscally independent districts, and the use of the property tax were all efficiency enhancing innovations. But each of them originated, most likely, in the pragmatic concerns of the day and not from a clear sense of the potential efficiency gains.

The often forgotten player in early educational funding is the federal government. Its role in the nascent years of the republic was considerably greater than it was to be later in U.S. history. A good case can be made that its fiscal role in those years was considerably greater than it has ever been in U.S. history.

\footnotetext{
${ }^{15}$ On local and state taxation, see Stewart (1914, pp. 77-92), who provides much of the evidence cited in this section.

${ }^{16}$ Fernandez and Rogerson (2003) analyze the impact on educational resources and equity of alternative school finance systems with an emphasis on the degree of centralization of school finance decisions.

${ }^{17}$ Hoxby $(1996,1999)$ discusses efficiency-equity tradeoffs, the importance of competition among school districts in efficiency, and the role of sorting among school districts within a Tiebout framework.

${ }^{18}$ On the role of property taxes, and the assumptions needed to obtain different incentive effects from the property tax as opposed to an income tax, see Hoxby (1996).
} 
The federal role in education was formalized at the very beginning of the nation when the Land Ordinance of 1785 was passed under the Articles of Confederation. Written by Thomas Jefferson it devised a way to deal with the lands in the northwest that were ceded to the federal government by the original thirteen states. Jefferson's plan divided the lands into townships, six miles square, each consisting of 36 mile-square sections. Each township was to receive one section to finance the schooling of its children. Two years later, in 1787, Congress adopted the Northwest Ordinance, which provided for the creation of from three to five states from these lands. Ohio, Illinois, Indiana, Michigan, and Wisconsin were eventually carved out of the Northwest Territories.

As the federal government acquired new territories the precepts of the Land Ordinance of 1785 were followed. Townships were surveyed with one section in each reserved to pay for schools. After California entered the Union in 1850 two sections, rather than one, were allotted to educational funds in each township, and four sections were allocated in the southwest due to the low value of land. ${ }^{19}$ The federal role in encouraging education through grants of land continued into the nineteenth century with land grants to the states to fund colleges, first in an ad hoc manner and later through the two Morrill land grant acts.

\section{Public funding of schools (Virtue 3)}

The passage of state legislation requiring school districts to provide for the schooling of youths has been seen as a turning point in the history of education, a crucial ingredient in the increased education of Americans and the hallmark of the egalitarian nation. The actual history is a bit more complicated.

\footnotetext{
${ }^{19}$ Among the states entering the Union after the original 13, only Maine, Texas, Vermont, and West Virginia did not receive land grants. Three of them were carved out of pre-existing states and Texas owned its own land. See, for example, Cremin (1951), p. 119.
} 
The movement for free schools emanated in the New England states, where the fervor for this public role was the greatest. It spread with the migration of New Englanders to the new lands of the Midwest and West, diffused into the Middle Atlantic states, and was eventually imposed on the South after the Civil War. The people of the various parts of the country, with the possible exception of the South, voted for their laws and their constitutions and created a greater role for government in the schooling of their children. But the precise manner in which free schooling was accomplished is a more involved tale. Many municipalities and other school districts had free schools long before the states required that they did, and public funding existed for some part of the school year even when tuition was charged for the remainder.

\section{The rate bills}

At the start of the new nation, the funding of schools was accomplished through a combination of state funds accumulated through the sale of public lands, parental contributions (rate-bills), and local taxes. The state funds were often adequate at first, but school expansion and the eventual depletion of the funds meant that other means had to be found. The search for additional funds led first to parental fees called "rate bills" and then to the use of local taxes, mainly the property tax, and state taxes. Rate bills were imposed at different moments in each state's history.

"Rate bills" were tuition payments for the use of public schools and were levied on families whose children attended the schools. In most communities these tuition payments were charged for days in attendance exceeding some number of days that were provided by the community free of direct charge. In others they were levied for the full term. Because the school teacher was the single most important expense, and often the only one, families in rural 
areas and even in some cities often paid for services "in kind" with the provision of room and board, in addition to a stipend.

In Massachusetts, a state at the forefront of education throughout the nineteenth century, towns with more than 50 families were required, beginning in the colonial period, to provide sixmonths of elementary schooling out of public funds. This requirement did not rule out the private payment by parents of additional sums to extend the term. In New York State, funds from land sales and other state sources supported local schools until 1828 when the use of rate bills began. From 1828 to 1868 these private fees provided half the salaries for teachers whereas state funds and local taxation provided the rest. ${ }^{20}$ Similarly in Connecticut, the sale of the state's Western Reserve lands in Ohio created a school fund of sufficient size to support local schools for some time. But as in New York at about the same time, rate bills were eventually imposed to provide additional funds.

The campaign for free schools in most states was a battle against the rate bill and a plea for alternative means to fund public schools. The crusade for free, common schools and for the abolition of the rate bill is one of the best known episodes in American educational history involving impressive figures such as Horace Mann, who led the campaign during the period between the Jacksonian era and the Civil War.

The abolition of the rate bills occurred in a complicated manner in many states, although in some it was relatively simple. Massachusetts and Maine, for example, abolished their rate bills before 1830, and New Hampshire never had one. Publicly provided common schools in most other northern states continued to be financed out of both public and private funds until the

\footnotetext{
${ }^{20}$ Cubberley (1934, orig. pub. 1919; chapter IV) and Randall (1844, p. 83) who provides annual data from 1815 to 1843 on the amount paid from the state treasury, that received by the districts, and that paid by individuals on rate bills.
} 
mid-nineteenth century, although several complications arise in the interpretation of the common school crusade.

The first complication in the abolition of the rate bills is that in many northern states the rate bill was abolished in major cities and other communities long before it was legislatively ended in the states in which they were located. Another complication is that the rate bill often covered only part of the total cost and its importance, therefore, will depend on the size of the fraction.

Families did not have to establish schools themselves in the larger and more densely populated cities of the North as they often did in the more sparsely populated rural areas. Rather, private schools of various types arose throughout the pre-Civil War era to serve the children of families who could afford the tuition. Some of these schools were relatively expensive elite institutions, but most were ordinary "common pay schools" that all but the very poorest used to educate their children. ${ }^{21}$ Pauper or charity schools served the rest and private schools occasionally forgave tuition for needy students. Churches and religious orders often supported the charity schools. The wealthier residents of the city funded some schools but various private schools actually received money from the city coffers. Ironically, as we shall see, the early coexistence in cities of private schools and pauper institutions eventually led to the creation of fully funded public schools long before free schooling came to rural communities.

The common school systems of the early republic formed, in essence, a patchwork quilt. Some communities had publicly provided and publicly funded schools. Of these, many allowed

\footnotetext{
${ }^{21}$ Kaestle (1973, chapter 2) remarks that school fees for "common pay schools" in New York City in the mid-1790s were low enough that all but the very poorest could attend. The fees he reports were about $\$ 2.50$ (or 20 shillings) per child per quarter. Annual family income would have been $\$ 250$ for a laborer who worked 250 days and around $\$ 350$ for a house carpenter working the same number (Adams 1967, table 1 for Philadelphia or New York City, see table 16). If a family had three school-aged children each
} 
parents to pay for extended days beyond those provided by the district. In other cities, most children were educated in private schools. Those without means were educated in pauper schools, which were communally or philanthropically supported and often church-based. Different educational institutions, therefore, arose in the larger cities than did in small towns and rural areas. Few places, however, in the era of the early republic were large enough to have a system of private schools, and since 80 percent of free Americans ( 84 percent of 5 to 14 year olds) lived in rural places and small towns in 1850, the system of quasi-public common schools with both taxes and rate bills predominated. ${ }^{22}$

\section{Free schooling for all: the common school crusade}

The funding of the common schools in the early republic differed greatly from what would soon unfold. What developed would be the enduring legacy of a movement to fund schools entirely out of local and state revenues and to rid the nation of rate bills and pauper schools. In the years before the Civil War an educational system evolved in which the community paid for the schooling of all its children.

Under this system the taxes of older property owners, whose children had already attended school, would pay for the schooling of other children, most likely those of younger members of the community. Communities would bond together in a system of "overlapping generations" in which the older members implicitly paid back to the community what they had received a generation before. Moreover, the schools would be "common" for all the children, no matter how poor the parents. With free schools for all, only the very wealthy would elect to send their children to private tuition-based schools and pauper schools would no longer exist.

of which went to school for two quarters a year, the fees would have amounted to 4 to 6 percent of annual income and a considerably larger fraction of income net of necessities.

${ }^{22}$ The definition of "rural" used here is any place with fewer than 2,500 people (IPUMS of the 1850 federal census of population). 
Full public funding for common schools spread throughout the northern and western states in the decades before the Civil War. The New England states were the first in the nation to make localities responsible for the education of all children in their district. The task was not fully complete until 1871 in the North and West and it was not until the 1870s that the South, with the reorganizations that followed the end of the Civil War, had free schools.

\section{How important was the common school movement?}

The year that rate bills were abolished is given in Table 4.1 for the states of the northeast and the "old northwest." Massachusetts and two other New England states abolished their rate bills in the Jacksonian era, although statewide free schooling legislation in Connecticut, Rhode Island, New York, and New Jersey was passed just after the Civil War. By 1871 the states in the older regions all had free schooling. In the 1870s free schooling was imposed on the states of the Confederacy.

One may wonder whether there is a clear relationship between the provision of free schooling and a state's first compulsory education law. In all states listed in Table 4.1 the first compulsory education law was passed after the rate bill was abolished at the state level. But the year of passage for compulsory education is only vaguely related in timing to the year of rate bill abolition. In part the absence of a clear positive relationship between the two laws may be because compulsory schooling laws were not generally effective until the early twentieth century. ${ }^{23}$

It should be clear from the inclusion of the South in the group of states with free schooling in the 1870s that the existence of public funding did not mean that schools were well funded. Even for the richer states, the quality of schooling varied across place and changed over 
time as the demand for better schooling increased. The average length of the Massachusetts public school session in the 1840s, for example, was about 165 days but it was about 192 days in the 1870 s. $^{24}$

The abolition of tuition payments in a state would seem to indicate that public schools became free over night and that the cost to parents of educating their children changed suddenly. That may have been the case in some states. But in most states the movement to free education was more gradual than is apparent in the law changes. The reasons are several and concern the complications raised above.

The significance of the demise of the rate bills depends on the fraction of the year that was paid for by districts prior to the establishment of free schooling. It also depends on the number of districts and municipalities that already had free schools prior to the abolition of the rate bill at the state level.

As we mentioned before, many municipalities, often the larger cities in the state, abolished school attendance fees earlier than did the entire state. The larger cities in New York, for example, and even some of the smaller ones abolished the rate bill long before the entire state did in 1867. New York City did in 1832, Brooklyn did in 1843, and many of the cities that lined the Erie Canal and prospered because of its commercial success did in the $1840 \mathrm{~s}^{25}$ Almost all the great port cities of the antebellum period, including those in the South, had free schools many years_-even decades — before their states abolished the rate bill. Two and a half decades before their respective states abolished the rate bill the cities of Baltimore, Charleston, Mobile, New

\footnotetext{
${ }^{23}$ Landes and Solmon (1972) provide evidence of the ineffectiveness of state compulsory schooling laws in the late nineteenth century. Goldin and Katz (2003b) analyze the impact of state compulsory schooling laws in the first half of the twentieth century.

${ }^{24}$ Kaestle and Vinovskis (1980), table A2.2.

${ }^{25}$ Of the top ten cities by population in New York in 1850, seven (ranked by size: New York City, Brooklyn, Buffalo, Rochester, Troy, Syracuse, and Utica) had abolished the rate bill by 1853.
} 
Orleans, and Louisville in the South had free schools, as did Cincinnati, Chicago, and Detroit in the "West" and Providence in the East. Even though Connecticut abolished the rate bill in 1868, the majority of school districts had established free schools about a decade earlier. ${ }^{26}$ Dubuque, and other Iowa school districts, had free schools in 1856, although rate bills in Iowa City covered half the total expenditures in $1857 .{ }^{27}$

Not only did many districts abolish the rate bill in advance of state legislation, but the number of publicly provided free school days, even in districts that had rate bills, was substantial in many districts. But we do not know of any comprehensive study giving the fraction of the school year paid by districts prior to rate bill abolition.

The shift in local finance from the levying of fees on families based on the number of weeks attended per child to taxation without any "user fees" should have increased enrollment and attendance if rate bills had mattered. But if the removal of the rate bills had little effect, either because the publicly funded term was sufficiently long or a substantial fraction of children already lived in free school areas, then school going rates would not change substantially. Evidence on the school enrollment and attendance of children before and after the abolition of the rate bill would bear on these issues, but such data are slender for the antebellum period and must be interpreted with caution.

Two of the most studied states in ante-bellum educational history are Massachusetts and New York. Several researchers have extensively used the records of these states, as well as those compiled by the U.S. census in 1830 and 1840 in its school censuses. Comparisons between the two states could be revealing because Massachusetts eliminated its rate bills in 1826 whereas New York State did in 1867, some 41 years later.

\footnotetext{
${ }^{26}$ This paragraph relies on Cubberley (1934, orig. pub. 1919), pp. 200.

${ }^{27}$ Aurner (1914, pp. 21-2, 47). All of Iowa's schools became free in 1858.
} 
Albert Fishlow, in a careful study of the antebellum common school "revival," reported that 73 percent of all 5 to 19 year olds in Massachusetts were enrolled in schools in 1830 and that 69 percent were in 1840. The comparable figures for enrollment in New York schools are nearly identical-74 percent in 1830 and 69 percent in $1840 .{ }^{28}$ These figures are rather high, perhaps because they represent enrollment and not attendance data.

The work of Carl Kaestle and Maris Vinovskis on ante-bellum Massachusetts schools makes this point clearer. They report average daily attendance rates among all children and youth under 20 years old was and find it was about 37 percent in Massachusetts over the entire period from 1840 to $1880 .^{29}$ Since in 1840,28 percent of this age group was under 5 years old and the attendance rate among infants and toddlers was about 22 percent ("infant schools" existed), the implied attendance rate for the 5 to 19 year olds was about 43 percent. Because "infant schools" decreased in importance, the implied attendance rates for the older children would increase after the $1850 \mathrm{~s}^{30}$

Other sources on ante-bellum educational statistics are the 1850 and 1860 U.S. population census manuscripts, which were put in machine-readable form sometime after these studies were completed. The census attendance rate in 1850 for (white) children 5 to 19 years

\footnotetext{
${ }^{28}$ Fishlow (1966a, table 1) uses mainly U.S. decennial census documents from the censuses of schools (as opposed to an actual census of individuals). The "school census" was continued in the 1850 to 1870 Social Statistics of the Census, although the censuses also asked individuals whether they attended school for at least one day in the previous year and also their occupation. We use those records to ascertain the accuracy of the attendance data in light of youthful labor.

${ }^{29}$ Kaestle and Vinovskis (1980), table A2.5. See also Vinovskis (1972).

${ }^{30}$ The attendance rate of 0 to 4 year olds (infants and toddlers) in 1840 in "infant schools" was about 22 percent. The attendance of those less than 4 years old is available before 1850 and is around 10 percent. But the data include those less than 5 years old after 1850. The data for 1849 suggest that a correction to the pre-1850 data would be to add 12 percentage points to the 0 to 3 year old rate to get the 0 to 4 year old rate. Attendance data are from Kaestle and Vinovskis (1980), table A3.1), and 1840 population data are from Census of the United States (1841), pp. 8-9.
} 
old in Massachusetts was 67 percent and 63 percent in New York. That for 1860 was 65 percent for Massachusetts and 62 percent for New York. ${ }^{31}$

There are several points we would like to make regarding the ante-bellum education statistics for Massachusetts and New York. Although the levels implied for youths are high, probably too high using the enrollment data, there is no reason to believe that the data for New York and Massachusetts are biased relative to one another. The comparison between New York and Massachusetts is telling. Around 1840 both New York and Massachusetts achieved almost equal enrollment rates for youths and these rates remained close in 1850 and 1860, during which time New York had not yet abolished its rate bill. ${ }^{32}$

Confirmatory evidence is provided by the states of the Midwest and reinforces the conclusion we draw from the New York and Massachusetts comparison. Schooling rates in the Midwest were substantial before the rate bills were abolished at the state level, even if adjustments are made to the census data. Enrollment rates in the Midwest were around 55 percent in 1850 and they increased by another 10 percentage points to 1860 . During that decade, or immediately before, four of the states (IL, IN, OH, WI) abolished their rate bills. Yet much of the increase in enrollment in the North Central area had already occurred. ${ }^{33}$

These findings do not indicate that the free schooling campaign was unimportant. On the contrary, the provision of free schooling mattered considerably to mass education. Rather, the point we are making is that many localities were already providing a considerable number of

${ }^{31}$ Computed from the IPUMS of the 1850 and 1860 population census.

${ }^{32} \mathrm{We}$ have not corrected the figures for differences in urbanization and other possible intermediating factors, but these would not lead us to reject the conclusion that the rates were similar between the two states. As is noted in Table 4.1, many of the larger cities of New York had free schooling long before the state abolished rate bills.

${ }_{33}^{3}$ Data for the Midwest are from Fishlow (1966a, p. 49) and are those from the school census. 
community-funded school days prior to the state abolition of the rate bills. ${ }^{34}$ In addition, many municipalities and school districts had free schooling for all prior to state abolition of the rate bills.

The case of the rate bills is one of many examples from U.S. educational history demonstrating that local control fostered educational expansion and that local districts expanded educational access before state mandates. ${ }^{35}$ Thus our findings, while not suggesting that the "free schools for all" crusade was unimportant, do point to the existence of and the importance of grass roots educational movements.

\section{Horace Mann and the "school men"}

Historical interest in the abolition of the rate bills stems in part from the importance of free schooling. But it also derives from the individuals who mounted the campaign to spread public schooling throughout the young nation. Whether or not their personal feats affected the end result is a matter of some dispute. What is clear is that they were dedicated people whose appeals and arguments were often decades ahead of their time. Among the best known were Horace Mann the secretary of the Massachusetts Board of Education from 1837 to 1848, and Henry Barnard his counterpart in Connecticut and Rhode Island, who served the former from 1839 to 1855 and the latter after his Connecticut position was temporarily abolished in the

\footnotetext{
${ }^{34}$ This is also the point made by Fishlow (1966a). According to Fishlow, increased enrollment in the 1840s and 1850s occurred, in many states, prior to the abolition of the rate bills. Only after enrollment increased did free schooling pass at the state level. Fishlow does mention that Louisiana was the only state in the South to adopt a free school law before the Civil War (in 1847) and that it experienced the third greatest gain in the South in (white) enrollment from 1840 to 1850. The other states (North Carolina and Tennessee) had increases in school revenue due to the distribution of the surplus (p. 52).

${ }^{35}$ We demonstrate a similar result with regard to state compulsory education and child labor laws in Goldin and Katz (2003b).
} 
1840s. ${ }^{36}$ Both Mann and Barnard published widely read journals that spread their ideas about free common schooling.

Horace Mann became the first secretary of the Massachusetts Board of Education in 1837, a decade after the state adopted legislation requiring localities to pay for all public schooling and constrained localities from imposing tuition charges. His goals, like those of other free school advocates throughout the nation, were to maintain the quality of the common schools, raise the standards for teachers, build more and better schools, and increase the length of the school year. To put it bluntly, Mann was a tireless advocate of mass education, and he used every honest tactic he could muster to achieve his goal.

In response to a decreased interest in public education around 1840 , possibly due to the depressed state of the economy but perhaps also to political events closer to home, Mann devised a way to convince the state legislators of the merits of an excellent public school system. ${ }^{37} \mathrm{He}$ constructed a questionnaire to demonstrate that education in the Commonwealth was to be valued because it produced efficient workers. He aimed to show that educated workers were productive on the job, adapted more easily to new technologies and even added to them.

Mann's questionnaire was ahead of its time in its empirical sophistication but was probably more a tool of propaganda than of scientific inquiry. "My object," he wrote "has been to ascertain the difference in the productive ability—-where natural capacities have been equal— between the educated and the uneducated." He chose "manufacturers of all kinds ... machinists,

\footnotetext{
${ }^{36}$ For a complete history of state educational offices, see Cubberley and Elliott (1915). New York, in 1812, appointed the first state officer to supervise schools, but the office was abolished in 1821 . Although in the 1820s some secretaries of state were asked to act as the state superintendent of schools, it was not until the 1840s that various states began to appoint individuals to a separate office of state superintendent of schools. In that sense Mann's position was a first in the history of state educational offices and was, according to Cubberley (1934, orig. pub. 1919), the first real state board of education in the United States.
} 
engineers, railroad contractors, officers in the army" who hired hundreds of people so that they could easily compare workers with a good common school education with those who did not have one. In his Fifth Annual Report (1841) he shared some of the responses with his readers. The responses he offered were few in number (in fact there were only five). Yet the summary of his findings went on for 20 pages of exhortations regarding the enormous gains from having an educated work force. ${ }^{38}$

\section{Was "free schooling for all" a grass roots movement or was it imposed?}

Horace Mann and his counterparts were dedicated, motivated, energetic individuals who formulated clever, often accurate, arguments for the public provision of schooling and its increased funding. But how important were they in moving the nation to embrace publicly provided and publicly funded education?

Some have read into this history that there was more behind the spread of public schooling than egalitarian virtues. A large and often contentious literature has emerged on the role of schools in socializing youth. ${ }^{39}$ Some historians have interpreted the documents of the past as showing that manufacturers and property owners wanted to fund schools to create a group of docile workers out of immigrant children, often Catholics. Yet another group of historians has interpreted increased schooling as a measure of the success of school bureaucrats in expanding their sphere of operations.

An important similarity among these arguments is the view educational expansion emanated mainly from those nominally in power. This interpretation gives credit to the

\footnotetext{
${ }^{37}$ See Kaestle and Vinovskis (1980), chapter 8 on Mann's political problems with the Massachusetts state legislature.

${ }^{38}$ Mann (1891, vol. III), pp. 94-5. Also see Vinovskis (1995), chapter 5, who is critical of Mann's empirical methodology.
} 
manufacturers, the large property owners, and the "school men," dedicated champions of free schooling. According to this argument, each of these groups may have had a different reason for expanding education or making it free, but they were unified in their desire to impose education on the masses.

A rather different view is that educational reform was largely a grass roots movement. It may have been hastened by the efforts of the "school men," but educational reform according to this view, was genuinely demanded by parents and the community. These two views of the spread of free common school education in the nineteenth century are repeated in the debates over the spread of secondary schooling in the twentieth century. ${ }^{40}$

Each of the arguments just mentioned contains certain elements of truth, some more so than others. Across much of America, mass education was a truly grass roots movement. Its popular base is clear from the referenda in many states that led to the passage of constitutional amendments, constitutions, and legislative statutes providing for taxation and free public education. $^{41}$ It is also clear from the role of the migration of New Englanders into the western lands and the institutions they brought with them. Yet it is also the case that public education was championed by energetic and persuasive "school men," such as Horace Mann, and that some manufacturers and property owners, particularly in the wake of the large migration of the Irish to New England, wanted to create Protestant Americans out of newly arrived Catholics.

The religious majority — the Protestants-also wanted to prevent the growing minoritythe Catholics - from gaining control of school funds. In one important case - that of New York

\footnotetext{
${ }^{39}$ See, for example, Bowles and Gintis (1976) and Field (1979), who uses cross-section evidence from Massachusetts to suggest that the Irish influx led industrialists to lengthen the school term for social control and other related reasons.

${ }^{40}$ Goldin and Katz (1999b, 2003a).

${ }^{41}$ For the details on the referendum for taxation in Indiana and for free schools in New York State, see Cubberley (1934, orig. pub. 1919), chapter VI.
} 
City - the battle over school funds led to the early separation of church and state in the provision of education. We explore this case in some detail because it is instructive for other reasons.

D. Separation of church and state (Virtue 4)

\section{Nonsectarianism}

Mann's Fifth Annual Report of 1841, which we discussed above, may have been motivated by political attacks on him in the Massachusetts legislature around 1839 concerning what others saw as his creation of "Godless schools." Mann, a Unitarian, wanted schools to educate all children regardless of faith and he espoused nonsectarian schools. The old-line Puritans in Massachusetts rose up in protest. After much debate, precipitated by a request by Catholics for a share of the state's educational funds, Massachusetts amended its constitution in 1855 to prohibit state and local funds raised for education to be awarded to sectarian schools.

The separation of church and state for Mann and others, it should be noted, did not bar the teaching of religion. Nonsectarian schools in the nineteenth century did not imply secular, "Godless" school rooms. ${ }^{42}$ Although maintaining the Protestantism of the schools was an important ingredient in the separation of church and state, the issue of commonality within Protestantism loomed large as well. The early to mid nineteenth century was a period of religious fervor in America that witnessed a proliferation of Protestant religions and the disestablishment in 1833 of the Congregationalist Church in Massachusetts. ${ }^{43}$ A common

\footnotetext{
${ }^{42}$ Mann, as well as many others throughout U.S. history who have been associated with the separation of church and state, espoused nonsectarian schools but not secular teaching. According to Mann: "Our system ... earnestly inculcates all Christian morals it founds its morals on the basis of religion; it welcomes the religion of the Bible ... But here it stops" (Mann 1891, vol. IV, pp. 222-340). See also Nord (1995) who notes that Unitarians allowed that schools could teach religious morals without reference to a particular theological system.

${ }^{43}$ See Michaelsen (1970) and Glenn (1988). The $3^{\text {rd }}$ article of the Declaration of Rights of the Massachusetts Constitution states "the people of this commonwealth have a right to invest their legislature with power to authorize and require ... towns, parishes, precincts ... to make suitable provision ... for the institution of the public worship of God, and for the support and maintenance of
} 
education for all Protestant children required that public schools be nonsectarian but did not require that they be secular. That happened much later. ${ }^{44}$

Six states had preceded Massachusetts in banning the use of state and local schools funds by churches. New Hampshire had done so in its constitution in 1792 as had Connecticut in 1818. New Jersey, Michigan, Ohio, and Indiana followed suit from 1844 to 1851 . All other states that had entered the Union before 1876 amended their constitutions to provide for the restriction regarding the use of school funds by religious bodies. All others were required, by an act of Congress passed in 1876 , to include the same prohibition in their constitutions. ${ }^{45}$ Figure 4.1 shows the relationship between the year a state entered the Union and the year it amended its constitution (or adopted one) that prohibited the use of public funds to support sectarian schools.

\section{The origins of free and nonsectarian urban schools: New York City as a case study}

Cities contained most, if not all, of the factions just described in the debates over free schooling. Nowhere is the story of free schools more replete with these factions and nowhere is there more intrigue involving them than in the story of the origins of free schools in New York

City. Religious charities, civic leaders, parents, local politicians, and state legislators all played a key role. $^{46}$

public Protestant teachers of piety, religion, and morality." With the change in this article, the Congregational order was disestablished.

${ }^{44}$ Not until 1963 did the U.S. Supreme Court, in Abington Township v. Schempp (374 U.S. 203), prohibit bible reading and the recitation of the Lord's Prayer in public schools.

${ }^{45}$ Cubberley (1934, orig. pub. 1919), p. 238. See Michaelsen (1970) and Stokes and Pfeffer (1964) on the narrowly defeated Blaine amendment voted in 1876 (63 percent of the House voted for it; 39 percent voted affirmatively on the Senate version). The House version of the Blaine Amendment read: "No State shall make any laws respecting an establishment of religion ...; and no money raised by taxation in any State for the support of public schools ... shall ever be under the control of any religious sect" (Stokes 1964, p. 434). The Senate version was similar. With the defeat of the Blaine amendment, a congressional law ("Enabling Act") was passed in 1876 requiring that all newly admitted states establish a provision in their constitution against the public support of sectarian schools (Michaelsen 1970, p. 68). All states had amended their constitutions or enacted legislation to present public funding for "sectarian" schools thus it was deemed reasonable that newly admitted states be required to do the same.

${ }^{46}$ This story has been well told by several historians, among them Kaestle (1973) and Ravitch (1974). 
In turn-of-the-nineteenth century New York City education was not a public concern. Private schools trained children whose parents could afford the tuition, and charity schools run by church denominations dealt with the others. Many of the private schools were relatively inexpensive, known as "common pay schools," and served working-class families such as those of the artisan or shopkeeper. The children of the poorer families either went without school or were schooled in the pauper or charity schools.

But by the 1840s New York City schools were publicly funded for all who wanted to attend. The turnaround that led to free schooling arose not because of the common school crusaders of the period of Horace Mann. Rather, free schooling in New York City triumphed largely because of the hard labor and cunning of those who founded an organization in 1805 to set up non-church based charity schools.

The organization founded in 1805 was originally called the Free School Society. At its inception it was a charitable, secular, private institution established to provide schooling to poor children who were not taken care of by church groups. It was run by well-known city fathers, such as its first president, De Witt Clinton. Beginning in 1806, the organization received state funds for its activities in serving the city's poor.

As the number of poor increased the Society sought greater funds, and it also endeavored to expand its mission. Catholics, who were just 2 percent of New York City's population in 1800 , were 16 percent in 1810, 18 percent in 1830, and about 22 percent in 1840-all before the great Irish potato famine and the mass emigration that followed. ${ }^{47}$ But the Society knew that curtailing the funding of church-based schools meant that it would increase its base of financial support.

\footnotetext{
${ }^{47}$ Kaestle (1973), table 19.
} 
By the 1820s the Free School Society began a campaign to put church-based charity schools out of business by denying them public funds and promising to provide free schools to all the children of New York City be they rich or poor, Protestant or otherwise. The campaign to deny funds to the denominational schools claimed success in 1825, and in 1835 the Free School Society group expanded its mission and changed its name to the Public School Society. The Public School Society functioned in much the same way current voucher systems or charter school systems do. The Society was a private organization that provided schooling for the city's children and was paid out of public funds. It offered, in essence, a publicly funded but privately provided education. ${ }^{48}$

The new Society opened schools in many parts of the city and could claim considerable success. But its success was fleeting and eventually led to the establishment of a governmental body to provide free, public schooling. An elective New York City Board of Education was founded in 1842 and with its establishment came a competing group of free public schools. The Public School Society had met its match. It disbanded in 1853 and turned over its schools to the city.

In sum, the free school movement in New York City was so successful that it ultimately resulted in the establishment of publicly provided, not just publicly funded, schools and its success resulted in the eventual elimination of the Society, an apparently unintended consequence. Another result—also possibly unintended—was the separation of church and state in the provision of publicly funded schooling in New York City.

\section{E. Gender neutrality (Virtue 5)}

${ }^{48}$ A rate bill that covered the entire cost of education, by comparison, was publicly provided but privately funded education. 
By the 1850s, and probably before, girls and boys throughout America were educated to about the same degree in terms of years of schooling to about age 15 (see Figure 4.2). Gender neutrality in years of education for youth was not always the case but arose during the first few decades of the nineteenth century. ${ }^{49}$

The data we employ to make this point come from the U.S. decennial population censuses for 1850 to 1880, which asked whether an individual attended school (for at least one day) during the previous year. As we noted above, the data from the U.S. decennial population census appear to give too high an estimate of the fraction of youths in school full-time. But there is no reason to believe that the upward bias was greater for girls than it was for boys.

The data for 1850 indicate that from about age 5 to 14 girls attended school—most often common schools - to about the same degree as did boys. ${ }^{50}$ Although boys began to lead girls in attendance at around age 14, the disparity was not substantial until age 16 when girls had a school participation rate about three-quarters that of boys.

The data for 1880 show that gender neutrality in school going had been extended by age. Nationwide, it was not until age 15 or 16 that boys had a somewhat greater school participation rates than did girls and the difference did not become substantial until age 17 when the ratio was 0.81.

\footnotetext{
${ }^{49}$ See Kaestle (1983) on educational changes from the colonial period to that of the Revolution when "Many elementary schools in the North admitted girls for the first time ... although access was often limited and segregated" (p. 28). Similarly, Kaestle and Vinovskis (1980) argue that much of the advance in school enrollments in the years from 1800 to 1830 occurred because of the increase in the schooling of girls (pp. 24-26).

${ }^{50}$ Whether or not mid-nineteenth century common schools were largely sex segregated is another matter. Some have argued that most common schools were intended to be sex segregated (e.g., Vinovskis and Bernard 1978), whereas others have convincingly demonstrated that boys and girls, especially in the less settled areas, learned together in practice (Tyack and Hansot 1990). Places that had sufficiently large populations, on the other hand, could afford to educate girls and boys in separate facilities.
} 
Although the data in Figure 4.2 are for the country as a whole, the expansion of gender neutrality from 1850 to 1880 varied by region. Larger relative gains for girls were made in New England and the Middle Atlantic than in the states of the Middle West. The West, just beginning to be settled in the 1850 s, emerged by 1880 as the most gender neutral of all. These relative gains for teenaged girls were rooted in the early extension of publicly provided and publicly funded schools to the secondary grades.

By the early 1900s the fraction of teenage girls who attended school was actually higher than it was for teenage boys and these differences were considerable. In the nineteenth century when schooling beyond age 15 generally took place in private schools and was often residential, parents did not always treat their teenaged daughters as the equals of their brothers. Thus the expansion of publicly funded high schools increased the number of youths who went to school and also encouraged parents to send their daughters to school.

Gender neutrality in attendance need not always imply equality in the type of education and one must also investigate the degree of coeducation. By 1891, according to a national survey, 93 percent of all major U.S. cities (of which there were 628 in the survey) had adopted coeducation in all grades of their public schools. ${ }^{51}$ Of the remaining 7 percent (or 42 cities) some grades, or some schools, educated girls and boys separately. Certain cities that had coeducational instruction in general contained some high schools that were reserved for boys (as in Boston, which had boy's and girl's Latin Schools) and these cities are included in the 42 mentioned above. In most cities, therefore, coeducation existed in all schools and in all grades. ${ }^{52}$ The rural schools were, according to the report, uniformly coeducational by 1890 .

\footnotetext{
${ }^{51}$ U.S. Commissioner of Education (1895).

${ }^{52}$ Larger cities would retreat from complete coeducation with the establishment of special secondary schools for vocational skills that were gendered.
} 
The gender neutrality that characterized American schooling by the mid-nineteenth century, and its schools and classrooms by the late nineteenth century at the very latest, is in stark contrast to that in the leading European nations of the day. Many European educators who were delegates to the Chicago Educational Congress of 1893 were shocked at the degree to which America educated its girls together with its boys. "It seems strange," noted one of the Prussian delegates, "to see boys and girls not only of 13 , but even of 16 years of age, sitting together or standing in mixed rows." The French were even more stunned. "Of all the features which characterize American education, perhaps the most striking," noted the female French minister of public instruction, "is the coeducation of young men and young women ... at least it is most striking to a French observer, for it reveals to him a state of mind and of habits which is entirely strange to him."

\section{F. Open and forgiving (Virtue 6)}

The U.S. educational system has been open and forgiving in comparison with other educational systems. By "open" we mean that almost all children could attend school. By "forgiving" we mean that one could often advance to higher grades and institutions even if one failed to perform adequately in a lower grade. The U.S. educational system of the nineteenth and much of the twentieth century was not, we emphasize, open to all children in all parts of the country, and it relegated many to inferior and segregated schools. But it was a far more open and forgiving system than were those of other economically important nations of the day.

Because the U.S. system was highly decentralized, there were no national educational standards and generally few state standards, a subject to which we will return in the discussion of secondary education. In England, France, and Germany, to the contrary, admission to publicly-

\footnotetext{
${ }^{53}$ U.S. Commissioner of Education (1895), pp. 799.
} 
funded schools beyond the elementary years, or in later years those of compulsion, was by examination, generally at the national level.

Prussia in the nineteenth century was a world leader in the education of its people at the lower grades. ${ }^{54}$ As early as 1812 regulations were imposed on the granting of the secondary school degree (the Abitur), which conferred eligibility for entrance to the university. In 1834 alternative methods for gaining entrance to the university were abolished and the Abitur became the only avenue. Similarly in France, Napoleon established a centralized educational system in 1808 in which entrance to higher education was highly restricted to those who passed a national examination, the baccalaureate. ${ }^{55}$ Because the "openness" and "forgiveness" of the U.S. system in comparison with that of other nations mainly concerns the transition to secondary and higher education.

\section{A note on nineteenth century education statistics}

In our discussion of rate bills and the role of "free schooling" in increasing the attendance of youth, we touched on the subject of nineteenth century educational statistics. The data derived from various federal census sources suggest very high rates of school going in the northeast. We also noted that such data could be reasonably interpreted as enrollment rather than attendance figures, as the comparison of Fishlow's data with that from Kaestle and Vinovskis for Massachusetts would suggest.

We return here to a discussion of educational statistics using data from the U.S. decennial population censuses from 1850 to $1880 .{ }^{56}$ These data are derived from the answers given to the

\footnotetext{
${ }^{54}$ See Easterlin (1981), for example.

${ }^{55}$ Ringer (1979), pp. 34.

${ }^{56}$ These data are similar to those used by Fishlow, although he also uses the school census data collected by the U.S. census.
} 
census concerning whether an individual had attended school during the past year. ${ }^{57}$ We will term these "enrollment" data since there is no information on the fraction of the year attended. Also of interest is whether a youth listed as having enrolled in school also indicated labor force attachment by declaring an occupation. ${ }^{58}$ We focus on the school enrollment of white youths. Enrollment levels for white youths were extremely high in the states of the northeast in 1850, equally high in the Midwest by the 1860 s, but trailed considerably in the South during 1850 to 1880 (see Figure 4.3 for a comparison between the northeast and the South, and Figure 4.4 on the northeast and Midwest). The overall enrollment rate of white youths 5 to 19 years old increased in all three regions from 1850 to 1860 , declined (especially in the South) in the decade of the Civil War, showed little change in the 1870s in the North, and increased sharply to recover back to the pre-Civil War level in the South from 1870 to 1880.

The changes in enrollment rates, however, differed substantially across age groups. Enrollment rates increased across all three regions from 1850 to 1880 for children 7 to 13 years olds. Older and younger children, for the most part, experienced a decrease in enrollment rates from 1850 to 1880 . Although the decrease might be interpreted as a backsliding in school participation that for the older age group should more accurately be interpreted as a sign of the greater effectiveness of schools. Many of the older children who enrolled in 1850, particularly in rural areas, were in common schools. As annual days of schooling and attendance increased,

\footnotetext{
57 "School" included public and private schools of various types, including common, grammar, high schools, academies, colleges, seminaries. Sunday schools (from 1850 to 1880) and evening schools (from 1860 to 1880) were explicitly excluded from the census definition of a "school." The U.S. decennial census has asked a similar question on school attendance in every subsequent census. A question on educational attainment was first asked in the 1940 census.

${ }^{58}$ The census asked the question on occupation of males older than 14 years in 1850, of all youths older than 14 years in 1860, and of all youths older than 10 years in 1880. The question on occupation apparently was asked of everyone in 1870 .
} 
these youths left school at younger ages rather than continuing with their elementary studies. ${ }^{59}$ The reason for the decrease at the lower ages is more complex and may concern state laws that allowed districts to restrict schooling to children above some age. ${ }^{60}$

The census data for 1870 and 1880 provide occupational information for individuals 10 years and older and thereby allow the calculation of a "full time schooling" measure for these youth. We assume individuals who both attended school in the past year and did not list an occupation in the census were engaged in full-time schooling. Because the comparisons between the total statistics and those for full-time schooling are no different between the two years, we have graphed, in Figure 4.4, only those for 1880. The full-time schooling fractions are lower than the totals, more so in the Midwest, where agricultural employment was greater, than in the northeast. But even though an adjustment for full-time schooling reduces the figures they remain substantial for youth in their early teens. ${ }^{61}$

Although youths could have attended school for the regular term and have been employed on their family farm or in a town either before or after school, it is more likely that most of them did not attend school for much of the term. Thus the schooling figures derived from the population census and other education statistics are somewhat exaggerated as a measure of actual school attendance.

IV. The origins of public high schools: from common schools, grammar schools, and academies

Even during the era of the common school movement and the campaign for free education, schools that provided training beyond the elementary level were already proliferating

\footnotetext{
${ }^{59}$ Public high schools were still rare outside the largest cities in 1880.

${ }^{60}$ Compulsory education laws accomplished this, but only Massachusetts had such a law until the mid1860s. The decline in "infant schools" in New England might also be a factor.
} 
in America. The schools in this group were of many types. They began chronologically with the Latin grammar school of the seventeenth century and were followed by academies and public high schools. By the mid-nineteenth century several, often-competing, institutions provided schooling beyond the usual common school years. These included public high schools, private and quasi-private academies, preparatory divisions of colleges, and even common schools.

The grammar or Latin schools are the oldest institutions in America that educated young men to enter the nation's colleges, and the earliest in America was the Boston Latin School (1635), which largely trained youths to enter Harvard College. There were never many of these schools and they were found in the larger cities of the colonies and in the states of the early republic.

Even by the early nineteenth century some parents of ordinary means in the larger towns and cities demanded an education for their children that went beyond the common school years. They wanted their children to be trained for positions in counting houses, mercantile establishments, and professional and business positions that, at the time, did not require the knowledge acquired in the colleges. To fill this demand, many of the nation's larger cities established free public high schools.

The first of these high schools, the English Classical School, was established in Boston in 1821 and during the next two decades about 30 public high schools were established in other Massachusetts towns. ${ }^{62}$ Even though an 1827 act of the Massachusetts Commonwealth required towns with more than 500 families to support a public high school, it is likely that these schools were founded for other reasons. Of the 20 largest Massachusetts towns in 1830, 15 had a high

\footnotetext{
${ }^{61}$ The reduction is greater considering just boys. For example, in 188051 percent of all 16 year old males in the Midwest were enrolled in school but just 28 percent were in school full time.

${ }^{62}$ Cubberley (1934, orig. pub. 1919), p. 259; U.S. Office of Education (1906), pp. 1855-63; Census of the United States, 1830 (1832), pp. 16-19.
} 
school by 1841, but so did 11 towns that were smaller than that defined by the law. Furthermore, many towns that would have met the size requirement did not have a high school even by $1860 .{ }^{63}$

Philadelphia established its first public high school, one that exists to this day-Central High School-in $1838 .^{64}$ The first public high school in New York City was not founded until 1848, although 25 years earlier a short-lived privately funded high school had been formed. ${ }^{65}$ Public high schools continued to expand in pre-Civil War America and by 1860 more than 320 were in existence. ${ }^{66}$

Throughout much of the nineteenth century the demand for public high schools in the sparsely settled parts of rural America and in its small towns was insufficient to warrant their provision. The public high school was viewed as a relatively expensive educational institution that would serve only a small fraction of the town or district youth. The external benefits that accrued from the common school, such as teaching children basic skills so they could function as good citizens and endowing them with republican virtues, were not a rationale for the high school. In rural communities, towns, and small cities, the common school often accommodated older youths, a practice that continued into the early twentieth century.

But even though most communities outside the large cities would not support a public high school, parents who wanted their children to extend their education beyond the common school years created a demand for private schools. By the mid-nineteenth century privately supported and provided secondary schools, called academies, emerged to fill this demand for post-elementary education. These academies grew so rapidly that many have referred to the

\footnotetext{
${ }^{63}$ The Massachusetts law was not seriously enforced. As a rough approximation to the 500 families rule, we use all towns with more than 600 white males older than 20 years.

${ }^{64}$ See Labaree (1988) for a history of the school's first century.

${ }^{65}$ The New York City high school was built with funds from the sale of stock and the stockholders reserved the right to place their own children in the school.

${ }^{66}$ Cubberley (1934, orig. pub. 1919), p. 262.
} 
period in the history of American education as that of the "academy movement." 67 Academies appeared just as the common schools were increasingly supported by public funds and were expanding their enrollments.

Academies of all types existed. In their laissez faire proliferation and unregulated growth they became typically American institutions. Academies could be college preparatory schools, of which some of the best, such as Phillips Academy, still exist. Most academies were not as excellent but gave, nonetheless, adequate training in academic subjects. Academies often taught vocational subjects, such as bookkeeping, surveying, drafting, and navigation that drew on academic subjects, such as mathematics, English, and history, they offered. Some academies taught music, dance, and other less scholarly subjects demanded by the parents of proper young women.

Because academies generally taught youths who resided outside the town, many of the schools boarded students from the surrounding rural areas. Although some academies were institutions of substantial size, many were established by a schoolmaster who taught his pupils at home. Even though academies charged tuition and were privately controlled schools run by trustees, many received subsidies from the locality or state, in the forms of land, buildings, and funds.

Because academies arose at the precise moment publicly funded high schools began to diffuse across the nation, they were largely ephemeral institutions. ${ }^{68}$ Academies folded as the competing publicly funded, and thus "free," institutions arose. Few survived for long, and

\footnotetext{
${ }^{67}$ There is but a small literature on the subject of nineteenth century academies. See, for example, Brown (1899), Cubberley (1934, orig. pub. 1919), Sizer (1964), and Tyack (1967, chapter 10).

${ }^{68}$ Kandel (1930) recounts the histories of academies in Illinois, Indiana and Michigan that existed until public high schools were established. Elsewhere, academies remained after the establishment of a public high school because the public high school did not offer a classical course, as was the case in Groton, MA (Katz 1968).
} 
although some left records most left none at all. For this reason we do not know the extent of their spread other than from the somewhat confusing social statistics collected at the county level for the 1850,1860 , and 1870 U.S. population decennial censuses. ${ }^{69}$

For the three census years-1850, 1860, and 1870 - the U.S. census, in addition to collecting information from individuals, farms, and firms for the censuses of population, agriculture, and manufactures, had its agents record a host of "social statistics" at the county level. The data they were asked to obtain concerned wealth, churches, libraries, poverty, schools, and the average wage for various occupations, among other variables. Although the precise questions varied by decennial census year, agents were asked in each of the years to obtain data regarding public schools, colleges, and "academies and other schools." The data concerned the number of schools, teachers, and pupils, as well as the annual income and its sources. Because of the paucity of other evidence on academies, the evidence in these documents has been widely cited. The data, however, require enormous care in interpretation. We will provide information from these unique data using, in addition, the extant state manuscripts of the Census of Social Statistics. ${ }^{70}$

The 1850 U.S. census of population reported that there were 6,032 academies nationwide with 12,297 teachers and 261,362 pupils. These figures have been repeated with great frequency in the educational history literature. ${ }^{71}$ They imply that the fraction of youths attending

\footnotetext{
${ }^{69}$ The data were supposed to be collected at the county level but in some cases (e.g., New York) the data were apparently collected at the township level, as is obvious from the manuscripts. The published data in the 1870 census include separate listings for "classical" academies and "day and boarding schools." The latter group included elementary school students, particularly in the southern states. Thus the 1870 published data are not usable in a study of academies.

${ }^{70}$ The manuscripts for various states are available on microfilm from the National Archives. Manuscripts are not available for all states. We thank Robert Margo for providing microfilms for AR, IA, IN, MA, MI, NY, PA, and TX.

${ }^{71}$ See, for example, Cubberley (1934, orig. pub. 1919), Kandel (1930), and Sizer (1964). Both Sizer (1964) and Kandel (1930) cite the 1850 census data on the approximately 6,000 academies and 260,000
} 
academies in 1850 was substantial. But these data, it appears upon closer inspection, do not refer just to the older academy students. Rather, in certain parts of the nation the lower grade students are also included.

If these academies served white youths nationwide between 15 and 18 years of age-that is, if their programs were for four years (the precise ages do not matter much for the calculation) — then the data on the number of pupils implies an enrollment rate of about 15.4 percent for white youths in America in the relevant age bracket. If, on the other hand, they were intended to last for two years, the enrollment rate for white youths would have been an astounding 30.8 percent nationwide. Finally, if male youths disproportionately attended academies, the figure would be higher for them alone. Any of these figures are extremely high for this early period. ${ }^{72}$

The census question asked about "academies and other schools," not just academies. The other categories on the form were public schools and colleges, and it is possible that the figures for academies also included other private schools and private tutors. Some simple calculations suggest that they did.

Another possibility is that the term academy in the Northeast and Midwest was reserved for schools that trained youths of secondary school age but that in the South it was also used to describe schools that offered instruction to elementary school children. In either case, the 1850 census figure would overstate the number of academies and their students in the South.

pupils from an article in American Journal of Education by Henry Barnard. There is no indication that the original data, available in published census reports, were consulted by either Sizer or Kandel, although Kandel correctly notes that "If these figures are accurate, one in every seventy of the white population attended an academy - a proportion not even yet realized in most European countries, and a little more than half of the proportion in high schools at the present time [1930] ... It must, however, be remembered that little is known about the average length of schooling of the pupils or about the standards of work" (p. 418). 
The 1850 census data imply that a higher fraction of youths in the South were in academies than in the Northeast and the Midwest. ${ }^{73}$ Assuming, as we did above, that academies enrolled youths for four of their teenage years (e.g., 15 to 18 years), the fraction who attended these schools in the South would have been 19.5 percent according to the census figures, 16.8 percent in the Northeast and 7.5 percent in the Midwest. ${ }^{74}$ But other sources (e.g., the population census data in Figure 4.3) indicate that the South had a lower, not a higher, fraction of youths in schools in 1850.

Another indication that the 1850 data on academies and their students have been misinterpreted or misreported is that the ratio of public school (meaning elementary or common school) pupils to academy pupils was rather low in the states of the South compared with other regions. The ratio was just 5.5 in the South but 14.7 in the Northeast and 31.5 in the Midwest. That is, the South had just 5.5 lower grade pupils for every academy student whereas the Northeast had almost three times that number and the Midwest almost six times. ${ }^{75}$ The academy data seem clearly overstated in the South. Although it is possible that youths in the South were taught at home by tutors until they left for academies, it is more likely that many of the reported "academy" students were in the lower grades.

The shortfall in the elementary and common school pupils in the South appears to have been incorporated in the academy data. In fact, the manuscripts of the 1850 census of social

\footnotetext{
${ }^{72}$ The number of (white) 15 to 18 year olds in 1850 was approximately 1.703 million (U.S. Bureau of the Census 1975, series A 123, assuming an equal number by single year of age for 15 to 19 year olds).

${ }^{73}$ We exclude the sparsely populated West in these calculations and use only those areas that were states in areas we now deem as New England and the Middle Atlantic for the Northeast, the South Atlantic, East South Central, and West South Central for the South, and the East North Central and the West North Central (excluding Missouri which is included in the South) for the Midwest.

${ }^{74}$ These calculations use the data on the number of academy students by state from DeBow (1853) and the total white population, 15 to 19 years old, by state multiplied by 0.8 from the same source.
} 
statistics reveal that there were many southern counties that did not list a single common or elementary school but in which an academy and its students were recorded. Although it is possible that a similar problem afflicts the data for other parts of the country, these areas had widespread common school system by 1850 . As is well known, the South lacked extensive public educational facilities in the nineteenth century and thus private schools such as "academies" (also home tutors) were substituted.

Thus the only quantitative data that exist on the academies—and those that have been used most extensively by educational historians—are difficult to interpret when applied to the entire nation. Our best estimate is that excluding the southern states the fraction of academyaged youths attending academies in 1850 was 13.5 percent, a hefty figure considering the fact that the (public and private) secondary school enrollment rate in these areas was about 24 percent some 60 years later in $1910 .^{76}$ Thus by mid-century academies were quantitatively important educational institutions, even though they probably were not as plentiful in the states of the South as the original documents have suggested. ${ }^{77}$

The academies were private institutions that charged tuition and were only rarely funded in part by the public. We have calculated tuition from the census manuscripts for two states (Arkansas and New York) and estimate that the per-pupil charge was about $\$ 15$ to $\$ 20$, or about

\footnotetext{
${ }^{75}$ In Massachusetts there were 14 public school students for every academy student, in Ohio there were 32. But in South Carolina there were but 2.4 public school students for each academy student, in Georgia there were 3.6, and in Virginia 7.5.

${ }^{76}$ The 1850 data exclude youths in public secondary schools. There were probably fewer than 100 schools in 1850 in the two regions considered, each with an average of about 150 students. Adding these public secondary school students to the academy totals would probably bring the total secondary school enrollment rate to about 15 percent in the Northeast and Midwest.

${ }^{77}$ Another possible reason for an overstatement of the number of academy students is that some students may have been enrolled in more than one school during the year. If that was the case for some youths, the calculated annual tuition payment would be somewhat understated.
} 
5 percent of the annual income of an artisan in $1850 .^{78}$ These schools were demanded by parents for their children and were distinctly the product of a grass roots movement to expand education.

Ever since the mid-nineteenth century, reformers had argued that free public high schools were an integral part of the democratization of education. ${ }^{79}$ But some questioned whether the various provisions of the states, which gave these units the ability to raise taxes to support the common schools, could also be used for the benefit of the high school. Without the ability to raise taxes, there could be no publicly funded high schools. The Michigan Supreme Court unambiguously answered the question in Kalamazoo (1874). ${ }^{80}$ The Kalamazoo decision set down the ruling that local funds could legitimately be used to support high schools. Many districts and municipalities across America had already used the state laws to raise funds for high schools. But the Kalamazoo case marked an important turning point because citizens had opposed using funds for high schools on the grounds that these schools did not educate the majority of the children. With Kalamazoo, this question no longer had validity.

\section{The origins of egalitarianism}

This chapter has traced the origins of the many virtues of American education-its public provision and public funding, existence of small fiscally independent units, separation of church

\footnotetext{
${ }^{78}$ The extant 1850 manuscripts we have are for AR, IN, NY, and TX. We used all the counties of AR and a sample of the townships of NY. We omit counties in AR in which there were no common schools and in which, therefore, "academy" pupils probably included the younger, common-school aged children. We compute the fees only for schools that listed "other sources" of income. The published census table (DeBow 1853, p. 142) sums the amounts across counties or townships even if the financial statement was blank. The census produced a "corrected" table (p. 143) that includes estimates for these blanks. An artisan in 1850 is assumed to earn \$1.50/day (U.S. Bureau of the Census, series D 719) and to work 6 days a week for 50 weeks per year.

79 "By the 1820s and 1830s, a growing network of reformers sought to ... lobby for a common system of tax-supported public high schools. ... school reformers began to argue that public high schools alone should provide advanced instruction for the talented few" (Reese 1995, p. 17).
} 
and state, gender neutrality, and openness. These features can be summed up as "egalitarian" in nature. The democratic, republican vision of education triumphed over an elitist one, in which private schools would exist for some and charity or pauper schools would serve the others.

The public provision and public funding of education were clearly part of the republican vision of an open and common system. The separation of church and state in the funding of schools was a logical extension of that view, as the case of New York City demonstrated. If denominational institutions received state funds, then children outside these denominations would be excluded, and children would not learn in a "common" setting. But the history of the Massachusetts ban on the use of state funds by sectarian schools suggests a different motive. The potential use of funds by Catholic churches prompted a prohibition on the use of funds by any denomination.

The creation of publicly funded common schools and their spread throughout much of America was the first great transformation of education in America. Even before free schooling spread throughout the states, with the abolition of "rate bills," education in America had surpassed that in any other country. ${ }^{81}$ Free public schooling, which had diffused nearly everywhere in the nation by the 1870 s, set the stage for the next great educational expansionthe growth of public high schools.

America's commitment to publicly-provided and, later, publicly-funded schooling began with a desire to create educated and informed citizens who could vote and stand for election. By the end of the nineteenth century, and probably before if Horace Mann's Fifth Annual Report is

\footnotetext{
${ }^{80}$ The decision, Charles E. Stuart et al. v. School District No. 1 of the Village of Kalamazoo, 30 Michigan (1874), is reprinted in Cubberley (1970, orig. pub. 1934), 159. The Kalamazoo Decision, p. 240. On the Kalamazoo high school and the opposition to it, see Reese (1995), pp. 76-9.

${ }^{81}$ Easterlin (1981).
} 
any guide, education was increasingly looked upon as it is today: as a means of acquiring skills for the world of work and for life in general. ${ }^{82}$

The second great transformation of American education— the high school movement—is part of that expansion in the role of education. As we have seen in this chapter, the second great transformation began slowly in the nineteenth century with the creation of public high schools in the nation's larger cities. Private academies increased the reach of secondary education through the mid-nineteenth century. But the second transformation picked up its greatest steam with the diffusion of public high schools, and in the first few decades of the twentieth century they had reached even the smallest rural communities in America.

The second transformation was built on foundations that were set down in the nineteenth century. The "virtues" of the past, largely put in place before the American Civil War, fostered mass education at all levels during the twentieth century. Whether these virtues have continued to be beneficial and whether some have become hindrances to educational excellence are issues for our future work.

\footnotetext{
${ }^{82}$ See also the many citations, from 1834 to 1880 , in Reese (1995), p. 96, fn. 52.
} 
Table 4.1

Free Schooling, the End of the "Rate Bills," and Compulsory Education Laws in the North and West

\begin{tabular}{|lcc|}
\hline State & $\begin{array}{c}\text { Year Rate Bill } \\
\text { Abolished }\end{array}$ & $\begin{array}{c}\text { Year of First Compulsory } \\
\text { Education Law }\end{array}$ \\
\hline New Hampshire & n.a. & 1871 \\
Maine & $1820^{2}$ & 1875 \\
Massachusetts & 1826 & 1852 \\
Pennsylvania & 1834 & 1895 \\
Wisconsin & $1848^{3}$ & 1879 \\
Indiana & $1852^{4}$ & 1897 \\
Ohio & 1853 & 1877 \\
Illinois & 1855 & 1883 \\
Iowa & 1858 & 1902 \\
Vermont & 1864 & 1867 \\
New York & $1867^{5}$ & 1874 \\
Connecticut & 1868 & 1872 \\
Rhode Island & 1868 & 1883 \\
Michigan & 1869 & 1871 \\
New Jersey & 1871 & 1875 \\
\end{tabular}

Sources: Rate bill abolition: Cubberley (1947, orig. pub. 1919), p. 205, which is consistent with Adams (1969, orig. pub. 1875); Fishlow (1966a) for Indiana, Iowa, and Wisconsin. Cubberley makes no mention of the New Hampshire and Maine dates. Compulsory education laws: Deffenbaugh and Keesecker (1935), p. 8.

Notes: In addition to the New York State cities mentioned in the footnotes to this table, Providence, Baltimore, Charleston, Mobile, New Orleans, Louisville, Cincinnati, Chicago, and Detroit, according to Cubberley, had free schools for about 25 years before their respective states abolished the rate bill.

${ }^{1}$ New Hampshire apparently never had a rate bill. See Bush (1898) and Bishop (1930).

${ }^{2}$ Cubberley (1934, orig. pub. 1919) notes that Maine's constitution (1820) required towns to "provide suitable support for schools." See also Chadbourne (1928) and Nickerson (1970) who make no mention of a rate bill.

${ }^{3}$ Fishlow (1966a) notes that Wisconsin abolished payments in its constitution, which passed in 1848.

${ }^{4}$ Fishlow (1966a) gives the date as 1851.

${ }^{5}$ Cubberley (1934, orig. pub. 1919) reports that many of the larger, and even some of the smaller, cities of New York provided for free schools long before the rate bill was abolished in the state. These include New York City (1832), Buffalo (1838), Hudson (1841), Rochester (1841), Brooklyn (1843), Syracuse (1848), Troy (1849), and Utica (1853). 
Figure 4.1

Year of Admission to Union and State Adoption of Constitutional Prohibitions Regarding Use of Public Funds for Religious Schools

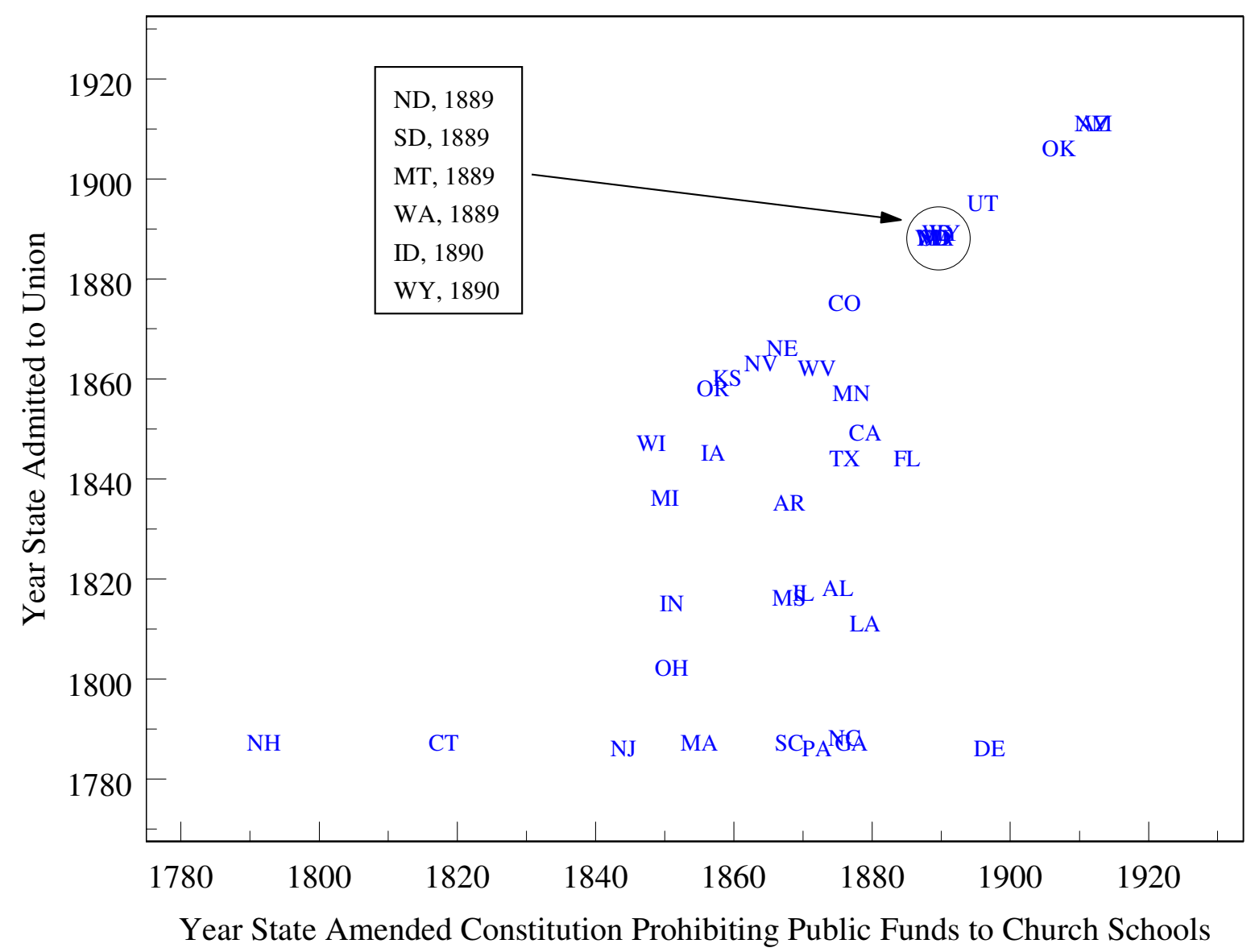

Sources: Cubberley (1934, orig. pub. 1919); Torpey (1964). 
Figure 4.2

School Enrollment Rates by Sex (for Whites): Females/Males, 1850 and 1880

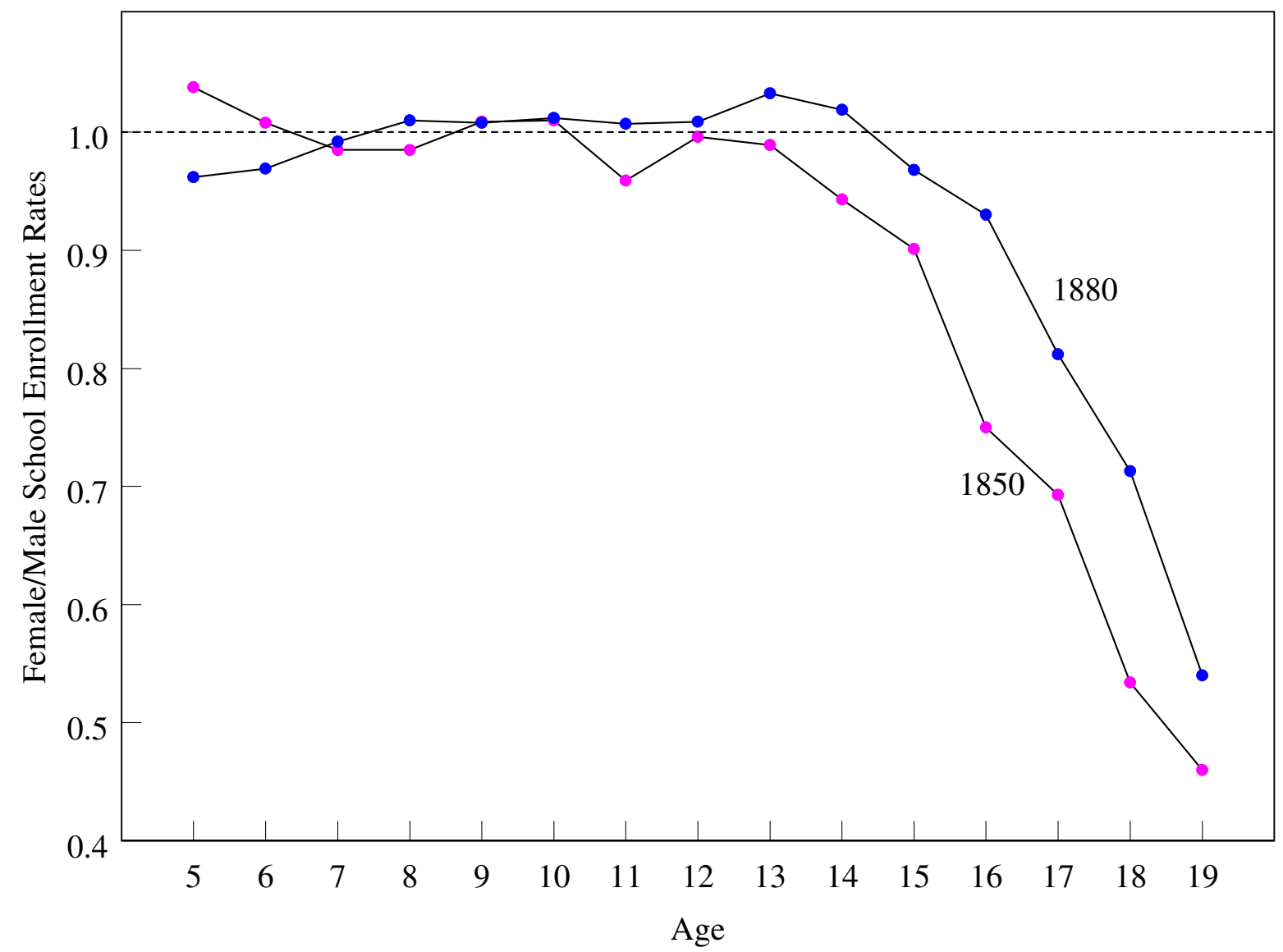

Sources: 1850 and 1880 IPUMS of the U.S. Census of Population.

Notes: The census asked whether an individual had attended school during the previous year. We interpret these numbers as giving school enrollment (see text). 
Figure 4.3

School Enrollment Rates for (White) Youths in the Northeast and South: 1860 and 1880

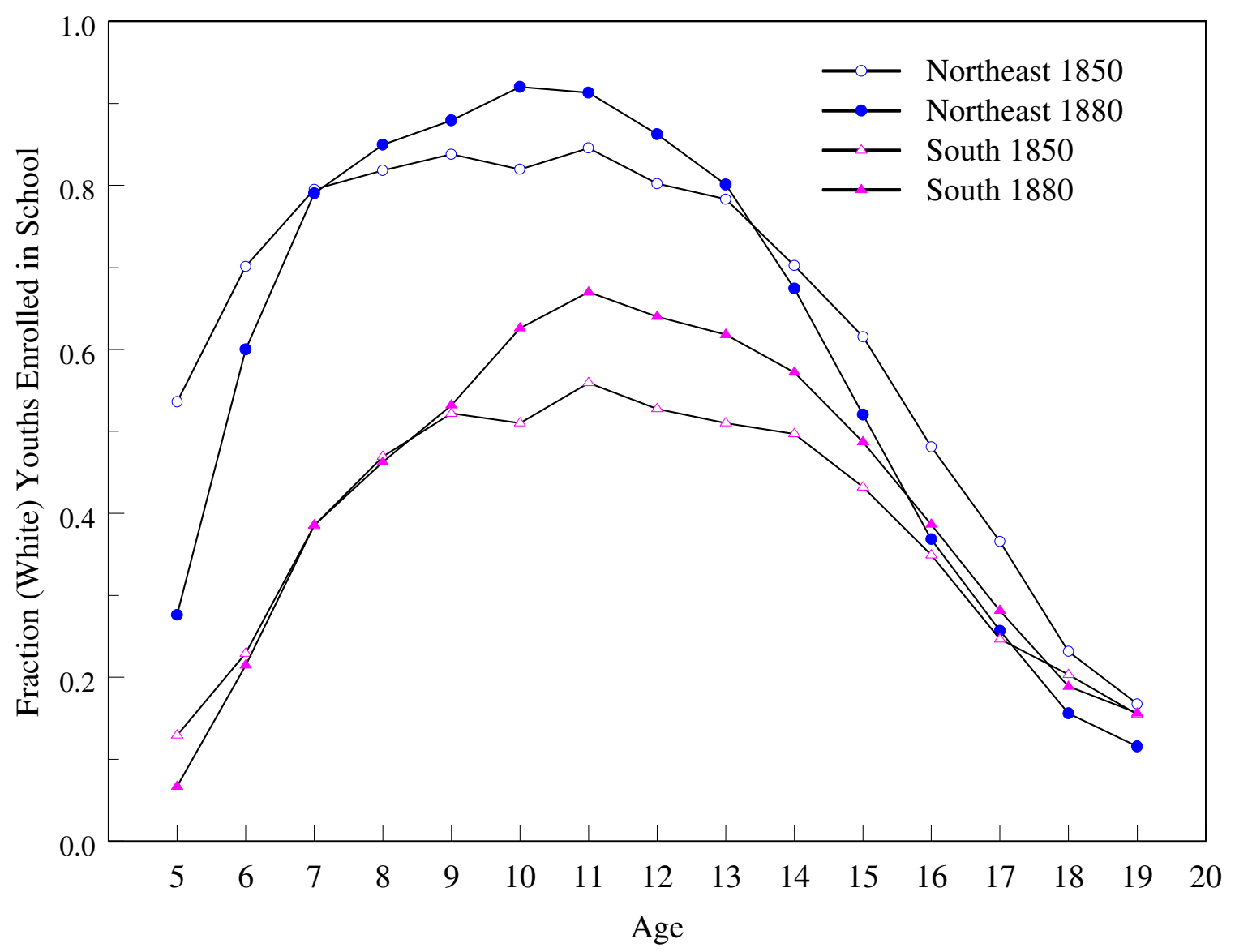

Sources: IPUMS of the 1860 and 1880 population censuses.

Notes: Northeast is the states of New England and the Middle Atlantic. South is the states of the South Atlantic. The school enrollment rate is the fraction of youth who reported attending school sometime in the past year. 
Figure 4.4

School Enrollment Rates for (White) Youths in the Northeast and Midwest: 1850,1860 , and 1880

\section{A. Northeast}

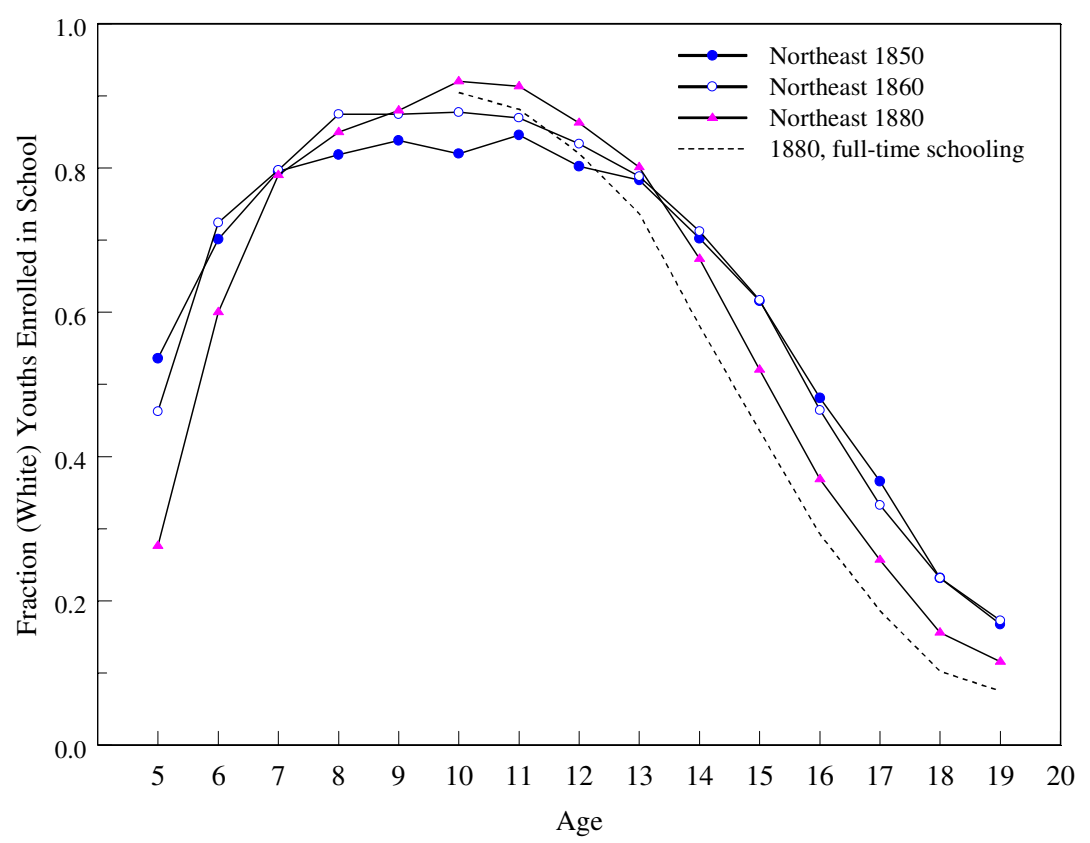

\section{B. Midwest}

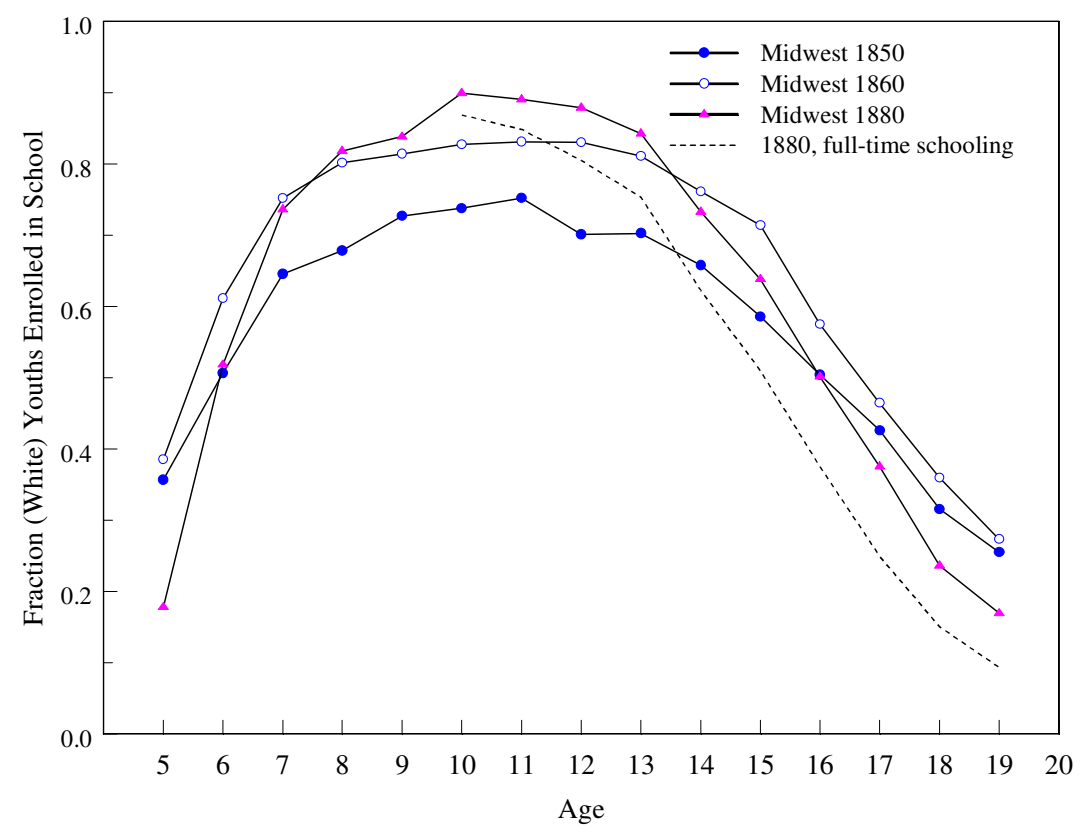


Sources: IPUMS of the 1850,1860 , and 1880 population censuses.

Notes: Northeast is the states of New England and the Middle Atlantic. Midwest is the states of the East North Central. The school enrollment rate is the fraction of youth who reported attending school sometime in the past year. The "full-time schooling" rate is the fraction of youth who both reported attending school and reported no occupation in the census. 


\section{Bibliography}

Adams, Francis. 1969, orig. pub. 1875. The Free School System of the United States. New York: Arno Press and the New York Times.

Aurner, Clarence R. 1914. History of Education in Iowa, Vol. VI. Iowa City, IA: State Historical Society of Iowa.

Bishop, Eugene A. 1930. The Development of a State School System: New Hampshire. New York: Teachers College, Columbia University.

Bowles, Samuel and Herbert Gintis. 1976. Schooling in Capitalist America: Educational Reform and the Contradictions of Economic Life. New York: Basic Books.

Brown, Elmer Ellsworth. 1899. Secondary Education. Monographs on Education in the United States. Department of Education for the United States Commission to the Paris Exposition of 1900. Albany, NY: J.B. Lyon Company.

Burdge, Howard G. 1921. Our Boys: A Study of the 245,000 Sixteen, Seventeen and Eighteen Year Old Employed Boys of the State of New York. Albany, NY: J.B. Lyon Co.

Bush, George G. 1898. History of Education in New Hampshire. Washington, D.C.: G.P.O.

Census of the United States. 1832. Fifth Census or Enumeration of the Inhabitants of the United States, 1830. Washington: Duff Green.

Chadbourne, Ava H. 1928. The Beginnings of Education in Maine. New York: Teachers College, Columbia University.

Cremin, Lawrence A. 1951. The American Common School: An Historic Conception. New York: Bureau of Publications Teachers College, Columbia University.

Cubberley, Ellwood P. 1934, 1947. orig. pub. 1919. Public Education in the United States: A Study and Interpretation of American Educational History. Boston, MA: Houghton Mifflin and Co. [Note: The 1934 edition was mainly used.]

Cubberley, Ellwood P. 1970. orig. pub. 1934. Readings in Public Education in the United States: A Collection of Sources and Readings to Illustrate the History of Educational Practice and Progress in the United States. Westport, CT; Greenwood Press.

Cubberley, Ellwood P. and Elliott, Edward C. 1915. State and County School Administration. New York: The Macmillan Company.

DeBow, J.D.B. 1853. The Seventh Census of the United Sates: 1850. Vol. 1. Washington: Robert Armstrong, Public Printer.

Deffenbaugh, Walter S., and Ward W. Keesecker. 1935. Compulsory School Attendance Laws and Their Administration. Bulletin No. 4, United States Department of the Interior, Office of Education. Washington, D.C.: G.P.O.

Easterlin, Richard A. 1981. "Why Isn't the Whole World Developed?" Journal of Economic History 61 (March): 1-17.

Fernandez, Raquel, and Richard Rogerson. 2003. "Equity and Resources: An Analysis of Education Finance Systems," Journal of Political Economy 111 (August): 858-97.

Field, Alexander. 1979. "Economic and Demographic Determinants of Educational Commitment: Massachusetts, 1855," Journal of Economic History 39 (June): 439-59.

Fishlow, Albert. 1966a. “The American Common School Revival: Fact or Fancy?” In Henry Rosovsky, ed., Industrialization in Two Systems: Essays in Honor of Alexander Gerschenkron. New York: Wiley Press.

Fishlow, Albert. 1966b. "Levels of Nineteenth-Century American Investment in Education," Journal of Economic History 26 (December): 418-36. 
Glenn, Charles L. 1988. The Myth of the Common School. Amherst, MA: University of Massachusetts Press.

Goldin, Claudia, and Lawrence F. Katz. 1999a. "The Shaping of Higher Education: The Formative Years in the United States, 1890 to 1940," Journal of Economic Perspectives 13 (Winter): 683-723.

Goldin, Claudia, and Lawrence F. Katz. 1999b. "Human Capital and Social Capital: The Rise of Secondary Schooling in America, 1910 to 1940," Journal of Interdisciplinary History 29 (Spring): 683-723.

Goldin, Claudia, and Lawrence F. Katz. 2000. "Education and Income in the Early Twentieth Century: Evidence from the Prairies," Journal of Economic History 60 (September): 782818.

Goldin, Claudia, and Lawrence F. Katz. 2003a, forthcoming. "Why the United States Led in Education: Lessons from Secondary School Expansion, 1910 to 1940." In D. Eltis, F. Lewis, and K. Sokoloff, eds., Factor Endowments, Labor and Economic Growth in the Americas. New York: Cambridge University Press.

Goldin, Claudia, and Lawrence F. Katz. 2003b. "Mass Secondary Schooling and the State: The Role of State Compulsion in the High School Movement," NBER working paper, forthcoming.

Hoxby, Caroline M. 1996. "Are Efficiency and Equity in School Finance Substitutes or Complements?," Journal of Economic Perspectives 10 (Fall): 51-72.

Hoxby, Caroline M. 1999. "The Productivity of Schools and Other Local Public Goods Providers," Journal of Public Economics 74 (October): 1-30

Kaestle, Carl. 1973. The Evolution of an Urban School System: New York City, 1750 to 1850. Cambridge, MA: Harvard University Press.

Kaestle, Carl. 1983. Pillars of the Republic: Common Schools and American Society, 1780-1860. New York: Hill and Wang.

Kaestle, Carl, and Maris Vinovskis. 1980. Education and Social Change in Nineteenth-Century Massachusetts. Cambridge, MA: Harvard University Press.

Kandel, I.L. 1930. History of Secondary Education: A Study in the Development of Liberal Education. Boston, MA: Houghton Mifflin Company.

Katz, Michael B. 1968. The Irony of Early School Reform: Educational Innovation in MidNineteenth Century Massachusetts. Cambridge, MA: Harvard University Press.

Labaree, David F. 1988. The Making of an American High School: The Credentials Market and the Central High School of Philadelphia, 1838-1939. New Haven, CT: Yale University Press.

Landes, William M., and Lewis C. Solmon. 1972. "Compulsory Schooling Legislation: An Economic Analysis of Law and Social Change in the Nineteenth Century," Journal of Economic History 32 (March): 54-91.

Lindert, Peter H. 2000. "The Comparative Political Economy of Mass Schooling before 1914." Unpublished paper. Department of Economics, University of California at Davis.

Mann, Horace. 1891. Life and Works of Horace Mann. Vols. III and IV. Annual Reports of the Secretary of the Board of Education of Massachusetts for the Years 1839-44 [III], 1845-48 [IV]. Boston, MA: Lee and Shepard Publishers.

Mann, Horace. 1841. Fifth Annual Report of the Secretary of the Board of Education of Massachusetts. [The Fifth Annual Report is included in Mann (1891)]

Michaelsen, Robert. 1970. Piety in the Public School. London: The Macmillan Company. 
Nickerson, Kermit. 1970. 150 Years of Education in Maine. Augusta: State of Maine Department of Education.

Nord, Warren A. 1995. Religion and American Education: Rethinking a National Dilemma. Chapel Hill, NC: University of North Carolina Press.

Randall, Samuel. 1844. A Digest of the Common School System of the State of New York. Albany, N.Y.: C. Van Benthuysen \& Co.

Ravitch, Diane. 1974. The Great School Wars: New York City, 1805-1973: A History of the Public Schools as Battlefield of Social Change. New York: Basic Books.

Reese, William J. 1995. The Origins of the American High School. New Haven, CT: Yale University Press.

Ringer, Fritz K. 1979. Education and Society in Modern Europe. Bloomington, IN: Indiana University Press.

Rudolph, Frederick. 1965. Essays on Education in the Early Republic. Cambridge, MA: Belknap Press of Harvard University Press.

Sizer, Theodore. 1964. The Age of the Academies. New York: Bureau of Publications Teachers College, Columbia University.

Stewart, Rolland M. 1914. Co-operative Methods in the Development of School Support in the United States. Iowa City, IA: Chestnut Printing Co.

Stokes, Anson Phelps, and Leo Pfeffer. 1964. Church and State in the United States. NY: Harper and Row Publishers.

Torpey, William George. 1948. Judicial Doctrines of Religious Rights in America. Chapel Hill, NC: The University of North Carolina Press.

Tyack, David B. 1967. Turning Points in American Educational History. Waltham, MA, Blaisdell Publishing Co.

Tyack, David B., and Elisabeth Hansot. 1990. Learning Together: A History of Coeducation in American Schools. New Haven, CT: Yale University Press.

U.S. Bureau of the Census. 1975. Historical Statistics of the United States from Colonial Times to 1970. Washington, D.C.: G.P.O.

U.S. Commissioner of Education. 1895. Report of the U.S. Commissioner of Education, 1891/92. Vol. 5, Part 2, Chapter XXVI. "Coeducation of the Sexes in the United States," by A. Tolman Smith. Washington, D.C.: G.P.O.

U.S. Commissioner of Education. 1906. Report of the U.S. Commissioner of Education, 1904. Vol. 2. Washington, D.C.: G.P.O.

U.S. Office [Bureau] of Education. [various years from 1916-18 to 1956-58.] Biennial Survey of Education for (various years from 1916-18 to 1956-58). Washington, D.C.: G.P.O.

Notes: We refer to this source as the Biennial Reports. After 1953, the Office of Education was housed in the Department of Health, Education and Welfare.

Vinovskis, Maris A. 1972. "Trends in Massachusetts Education, 1826-1860," History of Education Quarterly 12 (Winter): 501-29.

Vinovskis, Maris A. 1995. Education, Society, and Economic Opportunity. New Haven, CT: Yale University Press.

Vinovskis, Maris A., and Richard M. Bernard. 1978. "Beyond Catharine Beecher: Female Education in the Antebellum Period," Signs: Journal of Women in Culture and Society 3 (Summer): 856-69.

Watson, Tara. 2002. "Inequality and the Rising Income Segregation of American Neighborhoods," unpublished paper, Harvard University (June). 